This is an author produced version of a paper published in Forest Ecology and Management. This paper has been peer-reviewed and is proof-corrected, but does not include the journal pagination.

Citation for the published paper:

Marine Elbakidze1, Per Angelstam, Kjell Andersson, Mats Nordberg, \& Yurij Pautov. (2011) How does forest certification contribute to boreal biodiversity conservation? Standards and outcomes in Sweden and NW Russia.

Forest Ecology \& Management. Volume: 262 Number: 11, pp 19831995.

http://dx.doi.org/10.1016/j.foreco.2011.08.040

Access to the published version may require journal subscription. Published with permission from: Elsevier

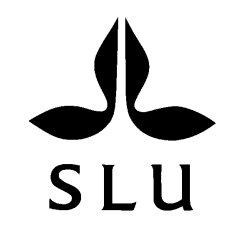

Epsilon Open Archive http://epsilon.slu.se 


\title{
How does forest certification contribute to boreal biodiversity conserva- tion? Standards and outcomes in Sweden and NW Russia
}

\author{
Marine Elbakidze1 (1), Per Angelstam (1), Kjell Andersson (1), Mats Nordberg (1), Yurij Pautov (2)
}

(1) School for Forest Management, Faculty of Forest Sciences, Swedish University of Agricultural Sciences, SE73921 Skinnskatteberg, Sweden;

(2) Silver Taiga Foundation, Post Office Box 810, Syktyvkar, Komi Republic, 167000, Russian Federation.

Published 2011 in Forest ecology and management 262, 1985-1995

\begin{abstract}
Forest Stewardship Council (FSC) is one of the leading forest certification schemes. While many studies concern political aspects and social outcomes of FSC, little is known about the contribution of certification to biodiversity conservation. In Europe, the Russian Federation and Sweden have the largest areas of FSC certified forest. We assessed the potential of FSC certification for boreal biodiversity conservation in terms of standard content, and outcomes as habitat area set aside and habitat network functionality. First, we compared the biodiversity conservation indicators at different spatial scales in Swedish and Russian FSC standards. Second, focusing on one large state forest management unit in each country, we compared the areas of formally and voluntarily set aside forests for biodiversity conservation. Third, we evaluated the structural habitat connectivity by applying morphological spatial pattern analysis, and potential functional connectivity by using habitat suitability index modelling for virtual species. The Russian standard included indicators for all spatial scales of biodiversity conservation, from tree and stand to landscape and ecoregions. The Swedish standard focused mainly on stand and tree scales. The area of voluntary set-asides for FSC was similar in Sweden and Russia, while formal protection in the Russian case study was three times higher than in the Swedish one. Swedish set-aside core areas were two orders of magnitude smaller, had much lower structural and potential functional connectivity and were located in a fragmented forestland holding. We conclude that to understand the potential of FSC certification for biodiversity conservation both the standard content, and its implementation on the ground, need to be assessed. We discuss the potential of FSC certification for biodiversity conservation with different levels of ambition. We stress the need for developing rapid assessment tools to evaluate outcomes of FSC for biodiversity conservation on the ground, which could be used by forest managers and FSC-auditors toward adaptive governance and management.
\end{abstract}

Keywords: structural habitat connectivity, potential functional habitat connectivity, virtual species, morphological spatial pattern analysis, pattern classes, boreal forest

\footnotetext{
${ }^{1}$ Corresponding author: School for Forest Management, Faculty of Forest Sciences, Swedish University of Agricultural Sciences, PO Box 43, SE-739 21 Skinnskatteberg, Sweden. Tel.: +46 (0)222-34971 e-mail: marine.elbakidze@slu.se
} 


\section{Introduction}

Almost half of the Earth's original forest cover is gone due to human activity, and much of it has been destroyed within the past three decades, leaving a forest cover of approximately $30 \%$ of the planet's total land surface (Anon., 1997). Only 20\% of the world's original forests remain in large intact near-natural forest landscapes, located mainly in tropical, subtropical and boreal forest biomes (Potapov et al., 2008). Three countries - Canada, Russia and Brazil - contain 64\% of the total intact forest landscapes (Potapov et al., 2008). Accelerated forest loss has led to serious consequences for biodiversity conservation (e.g., McNeely, 1994), as critical thresholds for habitat loss are passed (e.g., Angelstam et al., 2004c; Villard and Jonsson, 2009). It is thus urgent to prevent populations and ecosystems from tipping into undesired states, negatively affecting our ability to conserve forest ecosystem functions and services (Folke et al., 2004; Hansen et al., 2010; Rockström et al., 2009).

In the mid 1990s different forest certification schemes appeared in order to promote implementation of responsible forest management in both developed and developing countries as an answer to a gradual societal response to unsustainable use of forests. A hybrid set of actors including environmental nongovernmental organisations, publishing companies and critical citizens were the major drivers for the development of forest certification (Cashore et al., 2003, 2005; Gulbrandsen, 2005; Guynn et al., 2004; Hysing and Olsson, 2005).

The Forest Stewardship Council (FSC) is one of the most commonly adopted forest certification schemes, which aims to encourage responsible forest management at different levels from local to global (Auld et al., 2008; Cashore et al., 2003, 2005; Gulbrandsen, 2005; Gullison, 2003). The vision of the FSC is that "the world's forests meet the social, ecological and economic rights and needs of the present generations without compromising it for future generations" (http://www.fsc.org/vision_mission.html). This certification system was developed to "promote environmentally appropriate, socially beneficial, and economically viable management of world's forests" (www.fscoax.org/principal.htm). A global generic standard has been developed to define what well-managed forests are, which includes 10 principles and 56 criteria (www.fsc.org/certification.html). Additionally, nationally and locally developed standards are approved by the FSC if they conform to the scheme's global principles, criteria, and decision-making rules (www.fsc.org; Auld et al., 2008). In 1998 the first national FSC standard was endorsed in Sweden (Auld et al., 2008; Gulbrandsen, 2005). Globally, more than 135 million ha of forest are currently certified according to the FSC generic and different national standards, distributed in over 81 countries (www.fsc.org/facts-figures.html).

In this paper we focus on the FSC-certified forests in the boreal biome (Ahti et al. 1968) on the European continent. Being relatively remote from centres of economic development, the boreal forest is the least affected by exploitation and use among the European forest biomes (Hannah et al., 1995). Thus, there is still an opportunity to conserve higher levels of biodiversity conservation, including ecological integrity and resilience (Angelstam et al., 2004c), than in temperate forests. During the last years, the protection of boreal forests for mitigation and adaptation to climate change has also been highlighted (Carlson et al., 2009; Dise, 2009).

The FSC scheme is the only international certification system with wide geographical coverage in managed boreal forests in Europe. The vast majority of the FSC certified forests in Europe, i.e. including NW Russia, are located in the boreal ecoregion. Many studies have addressed the political and social outcomes of FSC (e.g., Bass et al., 2001; Cashore et al., 2003, 2005; Auld et al., 2008). However, little is known about the contribution of forest certification to biodiversity conservation on the ground (Gulbrandsen, 2005; Rametsteiner and Simula, 2003). Some consider forest certification to be an effective tool for biodiversity conservation in managed forests. For example, according to Gullison (2003), forest certification delivers biodiversity conservation benefits at least in three ways: (1) by improving the ecological value of certified forests for biodiversity, (2) by preventing conversion of forested land into agricultural land, and (3) by reducing logging pressure on high conservation value forests. At the same time, there is pessimism and critique concerning the role of forest certification for biodiversity conservation. This pessimism is based mainly on the perception and arguments among some actors who consider the concept of biodiversity as abstract, ambiguous and difficult to measure (e.g., Rametsteiner and Simula, 2003). Others have criticized the poor representation of biodiversity conservation principles in forest certification schemes (e.g., Bennett, 2000; Ghazoul, 2000). Successful conservation of biodiversity involves species, their habitat and the ecosystem processes that maintain them, i.e. about ecosystems' composition, structure and function (Noss, 1990). The amount and spatial configuration of habitat are the two key aspects affecting species and processes, and also properties 
that are directly affected by forest management. Thus assessment of biodiversity should include these two aspects. Generally, habitat loss is more important than the spatial arrangement of habitat (Fahrig, 1999).

Sweden and the Russian Federation have the largest areas of FSC-certified forest in Europe (Sweden with 11 million ha, and the Russian Federation with 22.9 million ha and a half of that in the European part) (www.fsc.org/facts-figures.html). Both countries also have clear national level policy ambitions to conserve biodiversity. The Swedish national forest and environmental policy objectives include maintenance of biodiversity as a sustained production capacity and conservation of viable population of naturally occurring species is emphasized (Swedish Forestry Act, 1993; Boström, 2002; Eriksson and Hammer, 2006; Angelstam et al., in press). The Russian Federation has signed many international conventions and developed a national strategy for biodiversity conservation (Anon., 2001).

The aim of this paper is to analyse the potential of FSC certification for boreal biodiversity conservation in terms of standard content, and outcomes on the ground in terms of setting aside forest stands. How do the national FSC standards in Sweden and the Russian Federation contribute to the national ambitions in biodiversity conservation through protection, maintenance and restoration of stands in managed forests? Is voluntary protection through FSC in combination with formal protection sufficient to conserve forest biodiversity, and with what level of ambition? To answer these questions we used large forest management units in Sweden and the Russian Federation, respectively, with similar biophysical conditions, but different forestindustrial regimes (sensu Lehtinen et al. 2004) as case study areas. We first analyse and compare the biodiversity conservation requirements at different spatial scales in national FSC standards in Sweden and the Russian Federation. Second, focusing on one large state forest management unit in each country, we compare the contribution of forests formally and voluntarily set aside to biodiversity conservation. Third, we evaluate the structural habitat connectivity by applying morphological spatial pattern analysis (Vogt et al., 2007a), and potential functional habitat connectivity by habitat suitability index modelling (Angelstam et al., 2004b; Store and Jokimäki, 2003) for virtual species (Mikusinski and Edenius, 2006). Finally, we discuss the potential of FSC certification for biodiversity conservation with different levels of ambition in Europe's managed boreal forests. We stress the need to develop a rapid assessment tool for evaluation of outcomes of FSC certification for biodiversity conservation on the ground which could be used by forest managers and FSC-auditors for adaptive management.

\section{Methodology}

\subsection{Study areas}

To select case studies for our analyses we defined four criteria to be satisfied, viz. similar size of the forest holding, type of the forest ecosystems and forestland ownership, and clear ambitions of forest stakeholders towards SFM implementation on the ground. The Bergslagen forest management district of Sveaskog Co. $\left(59^{\circ} \mathrm{N}, 16^{\circ} \mathrm{E}\right)$ (hereafter Bergslagen) in Sweden and the Priluzje state forest management unit $\left(60^{\circ} \mathrm{N}, 49^{\circ} \mathrm{E}\right)$ (hereafter Priluzje) in the Russian Federation’s Komi Republic were chosen as study areas (Figure 1).

Bergslagen encompasses a total area of 563,629 ha of forest land ownership, including water and mires. It is one of the five forest management units of Sveaskog Co., which manages the productive state forests in Sweden. The forested area of the holding is fragmented by land holdings of various forest owner categories and by transport infrastructure, and consists of many forest areas of different sizes dispersed over an area exceeding 4,000,000 ha within 9 counties in south-central Sweden. Bergslagen is located in the south and middle boreal ecoregions (Ahti et al., 1998). The main forest tree species are Norway spruce (Picea abies) and Scots pine (Pinus sylvestris). Forests with domination of birches (Betula spp.) and aspen (Populus tremula) occupy less then $8 \%$ of the total forested land of Sveaskog Co. A long history of sustained yield forest management $(E k, 1995)$ in the area has resulted in a loss of compositional, structural and functional elements of biodiversity found in naturally dynamic landscapes, and in the absence of any large intact forest areas. There are attempts to increase the proportion of deciduous trees to promote biological diversity and to provide the industry with hard wood timber (http://www.sveaskog.se/en/Forestry-and-Environment/Natureconservation). The environmental policy of Sveaskog Co. from 2003 states that $20 \%$ of productive forest land at tree, stand and landscape in each ecoregion should be used to promote environmental consideration and nature conservation (www.sveaskog.se/en/Forestry-and-Environment/Nature-conservation). Implementation takes place by setting aside (i) single trees and small group trees; (ii) stands, and (iii) landscapes in the so-called Ekoparks (Angelstam and Bergman, 2004); as well as (iv) by forming new protected areas. Sveaskog Co.’s forest management was certified against FSC in 1998. 
Priluzje is located in the south and middle boreal ecoregions of the south-western part of the Komi Republic in the Russian Federation's NW. The area of Priluzje is 810,252 ha, and it forms one contiguous block of forested land. Similarly to the situation in Bergslagen, the main tree species are Norway spruce and Scots pine. In contrast to Bergslagen, forests dominated of birch and aspen occupy almost $40 \%$ of the total forested land as a consequence of previous large-scale disturbances, by fire and logging, and due to absence of forest management. Priluzje still hosts pristine forests with natural dynamics and, consequently, near-natural composition, structure and functions. The forests classified as pristine in Priluzje occupy almost $12 \%$ of the total forested area (Anon., 2008a). Priluzje was the geographical area for development of the Komi Model Forest (MF) aimed at implementing SFM on the ground (Elbakidze and Angelstam, 2008; Elbakidze et al., 2010). One of the main outcomes of the Komi MF activities was the inventory and ecological evaluation of pristine forests in Priluzje, which was used in a decision-making process as to its conservation (Anon., 2005). In 2003 the forest management conducted by the forest administration in Priluzje became FSC-certified.

Both of the studied forest management units (Bergslagen and Priluzje) are in the process of certifying their forest management according to the requirements of new national FSC standards. In Russian the national FSC standard was approved in 2008 and in Sweden in 2010.

\subsection{Analysis of the FSC standard related to biodiversity}

Following Noss (1990) and Larsson et al. (2001), biodiversity can be defined as the composition, structure and function of an ecosystem. Successful maintenance of biodiversity thus means that all naturally occurring species exist with viable populations and are found in representative and functional (stable or dynamic) habitat networks maintained by resilient ecosystem processes at multiple spatial and temporal scales (Angelstam et al., 2004a). The extent to which biodiversity is maintained is therefore a matter of levels of ambition. There are, at least, four levels of ambitions for biodiversity conservation: (1) species may be present, but not in viable populations; (2) viable populations may be present, but only those that are not strictly dependent on natural forest structures or without large area requirements; (3) communities of all naturally occurring species of the representative ecosystems of an eco-region are present, but large scale natural disturbances and global change can threaten their ecological integrity, and (4) resilient forest ecosystems with a whole range of natural dynamic processes.

The level of ambition for biodiversity conservation correlates to a high extent to the spatial scale of forest management for biodiversity conservation under consideration. There are at least four relevant spatial scales: (1) The scale of "trees in a stand" including individual trees and groups of trees within a forest stand (Eriksson and Hammer, 2006). On this spatial scale presence of species with small habitat requirement could be maintained (the first level of ambition).

(2) "Stands in a landscape" correspond to the scale of a delimited area of similar tree species composition, age structure, diameter and height (Eriksson and Hammer, 2006). This scale matches the maintenance of species with small area requirements, such as vascular plants, but not viable populations of fungi and lichens in the long term (the second level of ambition).

(3) "Landscape scale" which is a large enough spatial extent to accommodate the needs of species with relatively large area requirements and habitat patch dynamics for species that track certain succession stages. According to Angelstam et al. (2004b), Brown et al. (2001), and Poiani et al. (2000) functional landscapes that encompass viable populations of most species native to a region can be recognized on a scale of tens of thousands to millions of hectares (the third level of ambition).

(4) Finally, "ecoregions" on the global level encompass the spatial scale which allows maintenance of ecosystem composition, structures, and functions linked to natural processes (Cabarle et al., 2000) (the fourth level of ambition).

To define the extent to which current criteria and indicators (C\&I) in the Swedish and Russian FSC standards (Anon., 2008b; Anon., 2009) capture these four spatial scales of biodiversity conservation, and thus implicitly the four spatial scales and linked levels of biodiversity conservation ambition, we analysed C\&I related to (1) direct actions (e.g., protection of certain species and its habitats), (2) indirect actions (e.g., emulation of natural disturbance processes in the forest management, and application of special silvicultural operations to maintain the ecological values of forest ecosystems). 


\subsection{Material and data for analyses of outcomes}

To obtain data about the age and tree species composition of the forest set aside for biodiversity conservation in Bergslagen and Priluzje we used the GIS-databases of the forest companies managing the two study areas. In Bergslagen, the last forest inventory was done in 1990, and since then it has been yearly updated taking into account the forest management activities undertaken. In Priluzje, the latest forest inventory was done in 1992 and it was updated in 2002. Overall, we used the records of age and tree species composition for almost 23,000 forest stand polygons in Bergslagen and 15,000 in Priluzje.

\subsection{Assessment of FSC outcomes for biodiversity conservation on the ground}

\subsubsection{Area proportion of set-aside forests}

In our study areas forests have been formally and voluntarily set aside for biodiversity conservation. The formal forest conservation is conducted by protecting different kinds of conservation areas according to the national legislation, and following the first principle of the FSC standard, which requires compliance with national law. The voluntary set-aside forests follow the FSC requirements and a particular company's policy framework.

To estimate the area proportion of all biodiversity conservation areas, we selected all formally and voluntary set-asides from the GIS databases for Bergslagen and Priluzje. Furthermore, taking into account that in our two study areas the forest management is in the process of becoming certified according to the revised national FSC standards, we conducted interviews with the representatives of forest management administrations to clarify what additional forest areas would be set aside to satisfy the new FSC requirements. The forest polygons which were pointed out by the forest management units as set-asides were also included into the analyses. It should be noted that we did not include in the analyses of single trees and small groups of trees set aside according to FSC requirements because these data could not be extracted from the forest inventory databases, and forest managers do not map these in a spatially explicit way.

\subsubsection{Assessment of structural habitat connectivity}

In addition to the area amount set aside for biodiversity conservation, the spatial configuration of forest patches is important to satisfy demands of species. Maintaining connectivity is thus an essential goal in biodiversity conservation (Fahrig, 2002). Following by Taylor et al. $(1993,2006)$ and With et al. (1997), there are two kinds of habitat connectivity: structural and functional. Structural connectivity describes physical relations among habitat patches and does not necessarily provide potential functional connectivity if corridors are not used by target species (Taylor et al., 2006). Potential functional connectivity is species-oriented and increases when a certain change in the landscape structure enhances the degree of movement or flows of organisms through the landscape (Taylor et al., 2006).

To assess structural habitat connectivity created by the forest stands formally and voluntarily set aside for biodiversity conservation in our two study areas, we used the Morphological Spatial Pattern Analysis (MSPA) (Ostapowicz et al., 2008; Soille and Vogt, 2009; Vogt et al., 2007a, 2007b, 2009). The MSPA has been used to quantify the structural (Ostapowicz et al., 2008; Vogt et al., 2007a, b, c; Wickham et al., 2010) and functional (Vogt et al., 2009) connectivity, and landscape fragmentation (Ostapowicz et al., 2008). It describes the geometric arrangements and connectedness of map elements and allocates each foreground pixel with set-aside forests to one of several mutually exclusive thematic pattern classes (Ostapowicz et al., 2008). Following Soille and Vogt (2009), we considered all seven classes of forest pattern: core, islet, edge, perforation, loop, bridge and branch (Table 1).

The formal and voluntary forest stands set aside in our study areas were merged to create the focal forest polygons for assessment of structural habitat connectivity for different forest types. All focal forest polygons were therefore classified according to age and tree species composition (Table 2). According to the MSPA method, connectivity could be set for four or eight neighbouring pixels. We used eight-neighbour connectivity in the data processing routine. According to Ostapowicz et al. (2008) and Soille and Vogt (2009), the MSPA classes on output maps depend on the spatial scale as defined by the pixel size of raster input data and the size parameter used in the morphological model. From a biological perspective, studies show that forest edges affect the environment in forest patches (e.g., Laurance and Yensen, 1991). We used the results of studies presented in Aune et.al (2005), Esseen and Renhorn (1998), Moen and Jonsson (2003), indicating that in boreal forests edge effects vary among species groups, although they generally extend to at least $25 \mathrm{~m}$ 
into the forest, and probably greater than $50 \mathrm{~m}$ for some groups (Aune et al., 2005). In view of this, the vector forests maps derived from the Geographic Information System (GIS) analysis of the forest management unit data were converted into raster maps with $25-\mathrm{m}$ pixels. The raster forest maps were re-classified into binary forest input maps that were composed of the foreground (forests set aside for biodiversity conservation) and the complementary background (other forests and non-forest areas). Finally, in the MSPA

processing we quantify connectivity in our study areas twice using an edge width of 25 and $50 \mathrm{~m}$, that is 1 or 2 pixels respectively.

\subsubsection{Assessment of potential functional habitat connectivity}

To assess the potential functional connectivity of set-aside forests in our study areas, we applied habitat suitability index modelling (e.g., Store and Jokimäki, 2003) using habitat variables and parameter values that represented focal species listed in the EU birds directive (EU 79/409/EES) or in boreal forest conservation planning (Angelstam et al., 2004a, 2004b; Mikusinski and Edenius, 2006). The focal species approach (Lambeck, 1997) is based on the idea that conservation of specialised and area-demanding species can contribute to the protection of many other naturally co-occurring species (Angelstam et al., 2003; Hess and King, 2002; Roberge and Angelstam, 2004). However, rather than focusing on given species, the habitat requirement of which may not be the same in Bergslagen and Priluzje, we employed an approach based on virtual (i.e. fictive) species (Hirzel et al., 2001; Mikusinski and Edenius, 2006). The potential functional connectivity of forests was estimated from the perspective of old-forest specialists with different ecological characteristics.

The creation of habitat suitability index models involved several steps. First, pixels of all forest pattern classes, which were created by the forests set aside for biodiversity conservation, were selected using output MSPA maps. Then habitat suitability index maps were elaborated for a suite of virtual species with patch size requirements of 1, 10, 100 and 1000 ha (c.f. Mikusinski and Edenius, 2006; Minor and Lookingbill, 2010). Finally, the nearest neighbourhood analyses (e.g., Manton et al., 2005) were performed for a local landscape habitat threshold of 20\% based on the experience from modelling (Andrén, 1997; Fahrig, 2002; With and King, 1999) and empirical studies (e.g., Angelstam et al., 2004c), corresponding to local neighbourhoods of 5, 50, 500 and 5000 ha, respectively. This provided an assessment of the potential functional connectivity of habitat tracts at the landscape scale that represents a range of relevant boreal forest focal species. This suite of analyses was implemented both for (a) what is old forest today (i.e. older than 110 years; Table 2), and (b) what will be old forest in the future, assuming that set-asides will neither be harvested nor subject to stand-replacing disturbance.

\section{Results}

\subsection{Requirements for biodiversity conservation}

The FSC's basic interim 10 Principles and Criteria for responsible forest management are the core of the national FSC certification standards in both Sweden and Russia. We extracted from the Swedish and Russian National FSC standards all indicators related to biodiversity conservation (for example, indicator 6.3.18 "Managers shall retain and safeguard, as part of all forestry measures, all trees with high biodiversity value" in the Swedish FSC standard) (Anon., 2009). In the Swedish FSC standard biodiversity considerations were included into 55 indicators and in the Russian FSC into 48 indicators.

Multiple indicators considered different aspects of biodiversity conservation. Both the Swedish and Russian FSC standards required the following actions for biodiversity conservation: (1) to retain relevant biodiversity value trees or groups of trees; (2) to protect species (rare, threatened, and endangered ones of plants, fungi, and animals red-listed as well as species vulnerable and sensitive to disturbances occurring within the forest area being certified) and (3) their habitats, (4) to mimic natural dynamics of a particular forest; (5) to protect sites of special social and ecological importance. In the Swedish FSC standard, special emphasis was put on the protection of wetland and aquatic habitats; and in the Russian standard attention was also paid to the protection of game species.

However, there were also nationally specific requirements in both standards. In the Swedish standard, there were indicators which required (1) exempting a minimum of $5 \%$ of the productive forest land area to maintain or promote biodiversity conditioned by natural processes or traditional land use practices; (2) increasing the role of broad-leaf trees which should constitute a minimum average of $10 \%$ of the stand volume; (3) 
maintaining the biological diversity of uncultivated meadows and pastureland where the species composition is still conditioned by former traditional management practices; and (4) protection of key woodland and forest habitats (Anon., 2009).

In the Russian FSC standard, there were indicators concerning (1) protection of large forest landscapes minimally disturbed by human activities; (2) protection of representative samples of existing forest ecosystems and rare and threatened types of ecosystems and landscapes; (3) monitoring the population dynamics of umbrella and keystone species, and (4) performing gap analysis to assess the extent to which the existing protected sites network provides conservation of regionally and locally rare and threatened types of ecosystems and landscapes (Anon., 2008b).

The indicators in both standards were thus relevant to biodiversity conservation at different spatial scales (Table 3). Some indicators referred to only one spatial scale, while others corresponded to several spatial scales. Our analysis showed that in the Swedish standard three spatial scales for biodiversity conservation were considered, with the majority of indicators being relevant to the finer scales of trees in a stand and stands in a landscape. In the Russian standard, four spatial scales were reflected, and the majority of indicators corresponded to the scales of stands in a landscape and landscapes in an ecoregion (Figure 2). Thus, both standards required set-aside of stands in a forest management unit, which implicates the need to assess outcomes both in terms of area proportions set aside as well as structural and potential functional connectivity.

\subsection{Assessment of FSC outcomes for biodiversity conservation on the ground}

\subsubsection{Area proportion of set-aside forests}

In Bergslagen, the formally set-aside forests included nature reserves created for the purpose of conserving biological diversity and valuable natural environments, or satisfying the need of areas for outdoor recreation, as well as nature of national interest with high natural or cultural value, which must be protected from actions that may significantly damage the natural environment (Boström, 2002; Naturvårdverket and Skogsstyrelsen, 2005, 2010). The total area of formally set-aside forest stands of all kinds occupied $3.3 \%$ of the total forested area in Bergslagen (Table 4).

There were also several types of forest stands set-aside on a voluntary basis according to the system of forest management classes required in the so-called green forest management plans (e.g., SOU 1997; LRF 1999), and applied by Sveaskog Co. These included: (a) forests to be left untouched in order to protect their high natural values (class NO); (b) forests to be managed in such a way so as to maintain high natural values (class NS), and (c) forests to combine wood production with the set-aside of trees and small patches of some natural or cultural value (class PF). The voluntary set-aside forests in Bergslagen covered $8.8 \%$ of the total forested area (Table 4).

In Priluzje, formally set aside forests fell into the following categories: (a) forests with water protective functions along rivers and streams (from $50 \mathrm{~m}$ up to $200 \mathrm{~m}$ on both sides), and along large rivers (from 1000 up to $3000 \mathrm{~m}$ ); (b) forests along roads (up to $250 \mathrm{~m}$ on both sides along main public roads); (c) forests along fish spawning areas (up to $500 \mathrm{~m}$ ); and (d) special protected areas (e.g., nature reserves of regional and local importance). The formally set aside forests amounted to $11.5 \%$ of the total forest area in Priluzje (Table 4).

The voluntary set-aside forests in the Russian case study were done according to the requirements of the Russian national FSC standard. These were pristine forest, defined as forest in its natural state, which had not been affected by any significant industrial and human influence, and thus developing according only to natural processes (e.g., Yaroshenko et al., 2001). In conformity with the Russian standard, this type is termed high conservation value forests (HCVF) group 2 (Anon., 2008b). There were also forests with high social and cultural values for local people, excluded from commercial use (HCVF groups 5 and 6) (Anon., 2008b). Together these forest categories occupied $10.4 \%$ of total area of forested land (Table 4 ).

\subsubsection{Structural habitat connectivity}

In Bergslagen, core and edge were the two dominant classes in the forest pattern when the edge width was defined as $25 \mathrm{~m}$. Taken together, these two classes occupied $70 \%$ of forested area set aside for biodiversity conservation. Branch and islet classes were also well represented (14 and 12\% of forested area, respectively) (Table 5). When the edge width was increased to $50 \mathrm{~m}$, the forest pattern became very different. The core 
area decreased almost to a third (from 36 to 13\%), while islet increased almost four times and became the single dominant pattern class (Table 5).

In Priluzje, the pattern of set-aside forest was very different from that in Bergslagen. With an edge width of $25 \mathrm{~m}$, core was the only dominant class, occupying 70\% of the total area of forest set aside for biodiversity conservation. The total area of two classes in Priluzje (core and edge) was equal to the sum of areas of four classes (core, edge, branch and islet) in Bergslagen. This shows that in Bergslagen the forests set aside for biodiversity were more fragmented than in Priluzje. With an edge width of $50 \mathrm{~m}$, the forest pattern changed. The core areas decreased to 47\%, and the area of branch and edge increased. However, these changes in proportion of forest classes due to different edge widths were much less pronounced in Priluzje than in Bergslagen.

In Bergslagen, pine, spruce and deciduous-coniferous forests occupied $84 \%$ of the total forested area set aside for biodiversity. Therefore, the majority of the forest pattern classes (core, edge, bridge and branch) were associated with these forest types, and mostly with pine forests. The coniferous-deciduous and deciduous forests occupied only $8.2 \%$ and $7.6 \%$ of the total area of set-aside forests, and the main pattern classes created by these forests were edges and branches (Table 5). In Priluzje, the deciduous and coniferousdeciduous forests were the dominant forest types set aside for biodiversity, and occupied $61 \%$ of the total area of formally and voluntary set-aside forests (Table 6). More than a half of the core areas were represented by deciduous and coniferous-deciduous and deciduous-coniferous forests. The edge was the second most common pattern class, represented mainly by deciduous, coniferous-deciduous and deciduousconiferous forests and also by spruce forests.

The majority of cores in Bergslagen (almost 70\% of the total number) were less than 1 ha large, and almost half of the total core area was located in a fairly low number of larger cores (with edge of 25 and $50 \mathrm{~m}$ ) (Figure $3 \mathrm{a}, \mathrm{b}$ ). In Priluzje the majority of cores ranged from 0.1 to 10 ha, however, more than $90 \%$ of the total core area were more than 1,000 ha (Figure $3 \mathrm{a}, \mathrm{b}$ ). The cores of over-mature and old forests were distributed on all forest types; however, the area proportions were different (Figure $4 \mathrm{a}, \mathrm{b}$ ).

\subsubsection{Potential functional habitat connectivity}

In both study areas over-mature and old forests were highly functionally connected for virtual species with small habitat requirements (1 ha). However, at other spatial scales the potential functional connectivity of these forests in Bergslagen and Priluzje was clearly different. For virtual species with area requirements of 10 ha the functionality in Bergslagen was low with the highest connectivity for deciduous-coniferous (around $40 \%$ of over-mature and old set aside forests) and the lowest connectivity for coniferous-deciduous old forests (less than 20\%). In Priluzje, almost 100\% of deciduous forests and $80 \%$ of spruce and deciduousconiferous over-mature and old forests were functionally connected for virtual species with 1 to 10 ha of habitat areas requirements (Figure 5).

In Bergslagen, over-mature and old forests were not functional for species with area requirements more than 100 ha. In Priluzje, the functionality of deciduous forests was high (almost 70\%) and medium (around 50\%) for species with habitats of 100 and 1,000 ha, respectively. For over-mature and old spruce and deciduousconiferous forests potential functional connectivity was low for the species with habitats of 100 ha. The functionality of over-mature and old spruce, pine, deciduous-coniferous and coniferous-deciduous forests was very limited or absent for species with area requirements of 1,000 ha (Figure 5).

If we assume that all forests set-aside for biodiversity in the study areas would be allowed to become old in the future, the analysis of potential functional connectivity showed that in Bergslagen (with 12.4\% of forests set-aside in the management area) the potential functional connectivity will remain the same for the species with habitats of 1 ha; will become better for the species with habitat of 10 ha specialising on old pine (up to $30 \%$ ), deciduous and coniferous-deciduous (up to 20\%) forests; and remain the same in deciduousconiferous and spruce forests. However, for species with habitats of 1,000 ha there will be no functional habitats. In Priluzje (with $21.9 \%$ of forests set aside), the potential functional connectivity of forests for the species specialising on biologically old forests with habitat requirements of 10 ha will remain high in all forest types, while for virtual species requiring habitat patch sizes of 100 ha will increase in pine and deciduous-coniferous (up to 20\%) forests, remain the same in spruce, coniferous-deciduous and deciduous forests. The functionality of forests for species with habitat area size requirements of 1,000 ha will remain extremely limited (Figure 6). 


\section{Discussion}

\subsection{FSC contribution to biodiversity conservation}

Our analysis of the indicators in the two national FSC standards shows that the requirements in the Russian standard clearly imply higher levels of ambitions related to biodiversity conservation than the Swedish standard. The indicators in the Russian standard correspond to the maintenance of communities of naturally occurring species, and to some extent ecological integrity and resilience of the representative ecosystems of an ecoregion. By contrast, the indicators of the Swedish FSC standard were focused at maintaining species not specialising on natural forest structures or with small area requirements. Thus, the same FSC label does not mean the same for biodiversity conservation in the managed forests in Sweden and Russia. Harmonization of indicators related to biodiversity conservation in national FSC standards is thus needed (Anon., 1996).

As to the outcomes of FSC implementation on the ground, our study shows that the implementation of national legislation for biodiversity conservation in managed forests plays a significant role as it determines the base level of forest protection for biodiversity conservation. For example, in our two case study areas the total area proportion of formally set-aside forest stands was almost three times larger in Priluzje than in Bergslagen. At the same time, the areas of voluntarily set-aside forests were similar in Bergslagen and Priluzje. However, it should be noted that the figure in Bergslagen is due to the environmental policy of Sveaskog Co., which goes beyond the 5\% of requirement of the Swedish FSC standard.

Based on our results of structural habitat connectivity, and using the results of many studies concerning the requirements of different species (Angelstam et al., 2004b; Belovsky, 1987; Biedemann, 2003; Edenius and Sjöberg, 1997; Jansson and Andren, 2003; Jansson and Angelstam, 1999; Linnell et al., 2005; Meffe and Carroll, 1994; Menges, 1991; McNab, 1963; Roberge and Angelstam, 2004), we conclude that the core patch size distribution was satisfactory in the Swedish case study for protection of plants, fungi and lichens, but not for area-demanding birds and mammals. By contrast, the majority of core areas in the Russian case study had the potential to host individuals of all the most area-demanding focal species. Additionally, the bridges and branches as narrow features in the forest pattern were more common habitat elements in Bergslagen, than in Priluzje. This indicates that the forest pattern may be more vulnerable to future edge effects, fragmentation and conversions to small isolated patches in Bergslagen than in Priluzje, which was dominated by large cores.

The set-aside forests were much better functionally connected in Priluzje than in Bergslagen. For species specialised on old forests the potential potential functional connectivity of forests in Bergslagen was currently very limited or absent today. The situation will remain unchanged in the future if it is assumed that setaside forests would not be harvested and allowed to develop old forest characteristics. The set-aside forests were only well functionally connected for virtual species with habitat requirements of 1 ha. By contrast, in Priluzje the set-aside forests were functionally connected for virtual species with habitat requirements from 1 to 100 ha.

We used the virtual species approach to assess the potential functional connectivity of forest set-aside in our study areas. The different patch size and patch density parameter values can be translated to real species. The reason for this is that size of landscapes from the point of view of particular species or group of species (sensu Wiens and Milne, 1989) are dependent on their life-history traits. The lichen Lobaria pulmonaria, the white-backed woodpecker Dendrocopus leucotos and the reindeer Rangifer tarandus are three examples of focal species with different area requirements. Lobaria pulmonaria is found in deciduous-coniferous forest containing deciduous trees with a high $\mathrm{pH}$ on the bark and a light and moist microclimate (Öckinger and Nilsson, 2010). Assuming a 100-m buffer of old forest to allow for blow-down of trees at the edge, and the maintenance of a moist local climate in a 1-ha area including 500 trees, corresponds to a stand size of ca. 5 ha. Assuming that such stands cover 2\% of the landscape as Swedish key biotopes do (e.g., Hansson, 2001), and that the suitable window in time in the succession is $20 \%$ of the rotation of $100 \mathrm{yr}$, the area needed for a population is $((5 / 0.02) / 0.2)=12.5 \mathrm{~km}^{2}$. For the white-backed woodpecker Angelstam et al. (2004) estimated the area for a population of 100 units to $5000 \mathrm{~km}^{2}$. In Sweden wild reindeer are extinct, and Finland reindeer it is threatened (Kojola et al 2009). Large intact forest areas are needed to maintain this species including its interactions with large carnivores (Schneider et al. 2010). These estimates illustrate that the area to be considered for the maintenance of populations of these real species differ by two orders of magnitude between the lichen and the woodpecker, and by four orders of magnitude between the lichen and the mammal.

The spatial modelling approaches applied in this study to assess habitat network functionality show that to estimate outcomes from FSC only in terms of the total area of set-asides severely overestimates how much 
habitat is actually functional. This is valid even if we assume that all set-asides eventually have the opportunity to become restored to older and old-growth forests in the long term. Additionally, when considering temporal dimensions of habitat network functionality, it should be noted that there are other sources of overestimation due to the uncertainty about the survival and fitness of species' individuals, populations and meta-populations over longer time periods. Extinction debt is a term that captures the time delay necessarily involved in the regional extinction of species following habitat loss and fragmentation (Hanski et al., 1996; Hanski, 2000). For example, by studying temporal changes in occurrence of the focal lichen species Lobaria pulmonaria Öckinger and Nilsson (2010) demonstrated that the expected lifetime of ramets was about 40 years, i.e. much lower than the longevity of potential host trees. The probability of presence of fertile ramets increased significantly with local population size. In Finland, this kind of extinction debt of boreal forest species is estimated to the order of 1000 species (Hanski, 2000).

This study also has some limitations. First of all, validating the modelling approach to the assessment of potential functional connectivity of forest landscapes in the areas requires field data obtained through direct observations of target species' movement, fitness and persistence in a given landscape. In practice, forest managers are generally not able to gather such data, which have to be collected as in a carefully designed experiment within an adaptive management framework. It is urgent to understand the potential of managed forests to maintain biodiversity with different levels of ambition, which requires both assessments of the functionality of set-asides and their cost-efficiency (Gustafsson, 2002). Nevertheless, the assessment approach proposed in this paper could be used for rapid evaluation of structural and potential functional connectivity of set-aside forests in certified forest areas. This is needed for credibility and further progress of forest certification. The approach and technique proposed in this paper could be easily implemented by the FSC-certified forest companies as well as FSC-audit certification organisations. Secondly, we analysed structural and potential functional connectivity only of set-aside forests. We did, however, neither analyse the suitability of other forests and types of ecosystems (bogs, wetlands etc.) for virtual species, nor the permeability of the matrix surrounding the formally and voluntarily set aside forests. The reason it that we assumed that under continued intensive forest management, which is focusing on production of wood mainly for pulp industry and bioenergy, the forest outside of set-aside would be not suitable for species specialised on old-growth forests in the long term (e.g., Kuuluvainen, 2009).

To sum up, based on the results of our study, we conclude that FSC certification does contribute to biodiversity conservation, but the level and efficiency of this contribution depends on standard content, and how it is implemented on the ground. At the same time, the role of national legislation or policy for biodiversity conservation remains critically important. Consequently, to understand the effects of conservation efforts in managed forests, both informal and voluntary set-asides need to be considered.

\subsection{Need for a diversity of biodiversity conservation tools}

National forest certification standards are results of voluntary negotiations among stakeholders with different goals and power. The initial prerequisites for implementation of national FSC standards are thus contextdependent because countries and regions have different forest-industrial regimes (Lehtinen et al. 2004). Additionally, individual forest companies have own ambitions, abilities and professional knowledge for application of own standards that are higher then those of FSC.

Apart from different formal and voluntary policy statements, Sweden and Russia have different boreal forest histories (Angelstam et al., 1997), which are likely to influence the potential of forest set-aside as a biodiversity conservation tool. In Sweden, a long history of sustained yield forest management has resulted in a biased representation of the protection of different ecosystem types (Angelstam and Andersson, 2001; Nilsson and Götmark, 1992), as well as loss of compositional, structural and functional elements of biodiversity (Esseen et al., 1998; Nilsson et al., 2005), and thus in the need for ecosystem restoration (Angelstam and Andersson, 2001; Angelstam et al., 2005). In the Russian Federation, the situation is, so far, quite different. Due to a shorter history of industrial forest use in Russia remnants of naturally dynamic forests are more abundant than in Sweden (e.g., Yaroshenko et al. 2001). Russia's boreal forests in the eastern part of the European continent thus play an important role in forest biodiversity conservation on a global level, since the country hosts the last large intact areas of boreal forest ecosystems with natural range of variability in terms of their composition, structure and function (Aksenov et al., 2002; Yaroshenko et al., 2001; Shorohova and Tetioukhin, 2004). At the same time, however, large regions of the Russian boreal forests are severely affected by an accelerated harvesting of wood during the last decades (e.g., Burnett et al., 2003; Elbakidze et al. 2008), and the intact forest landscapes are shrinking by 3\% annually due to logging (Mayer et al. 2005). 
However, the argument concerning the relatively small area of old-growth forest remnants in Sweden due to a long history of intensive forest use does not diminish the fact that on the national level in Sweden there is a high ambition to protect viable populations of naturally occurring species (Naturvårdverket and Skogsstyrelsen, 2005). This means that the efforts to restore forest biodiversity in managed forest landscapes, should also be reflected by the indicators formulated in the national FSC standard. The minimum standard of 5\% set-asides as required by the Swedish National FSC standard is obviously not enough to maintain or restore biodiversity with moderate and high level of ambitions in the boreal forest landscapes (e.g., Svancara et al. 2005; Angelstam et al., in press).

In the context of biodiversity conservation it generally pays off to concentrate efforts on improving forest quality in certain areas, rather than to spread out the same effort evenly and thus thinly across the forest landscape (Hanski, 2000). While in Russia there is only one forest owner (the state), Sweden's forest are owned by public owners, the state forest company, Sveaskog Co., and industrial and non-industrial private forest owners. It should also be noted that while the Russian case study area was a contiguous area of more than 800,000 ha, the Swedish forest management unit of 500,000 ha was made up by an archipelago of forestland holdings spread out over more than 4,000,000 ha, with inter-dispersed holdings of thousands of nonindustrial private forest owners, several other forest companies and patches of other publicly owned forestland (Figure 1). The spatial configuration of different land owners' holdings is usually very complex, which requires collaboration at the level of landscapes and even regions to affect the spatial configuration of patches. Therefore, to implement biodiversity conservation policies in Sweden, clearly, formal conservation efforts need to increase, conservation interaction among forest owners have to improve (Angelstam et al., in press), and the Swedish FSC-standard be revised accordingly.

In Russia implementation the FSC standard in the Priluzje forest management unit was accompanied by the long-term education of forest managers about biodiversity issues and cooperation with the regional and national research organisations aimed at identifying and mapping the pristine forests and HCVFs. This was conducted in the frame of Komi Model Forest's activities (Elbakidze et al., 2010). However, it is doubtful if the quality of FSC implementation in an "ordinary" forest management unit would be the same as in Priluzje, taking into account the complexity of the Russian standard which requires special deep professional knowledge.

To conclude, a diversity of tools is needed to improve or implement evidence-based requirements related to biodiversity conservation in managed forests. The role of national FSC standards is positive, but need to be integrated with other tools, such as formal forest protection. In addition the role of green tree retention on harvested areas need to be understood. Collaboration between different stakeholders, education and monitoring of the implementation progress is therefore crucial.

\section{Acknowledgements}

The research councils FORMAS and Marcus och Amalia Wallenberg Minnesfond provided funding that enabled us to carry out this study. This paper has benefited greatly from the constructive comments of Olof Johansson, Carina Keskitalo, Jacek Kozak, Per Larsson, Grzegorz Mikusiński, Jean-Michel Roberge, Peter Roberntz, Camilla Sandstöm, Peter Vogt and Tatyana Yanitskaya. Additionally, anonymous referees provided valuable comments and insight while developing this manuscript.

\section{References}

Ahti, T., Hämet-Ahti, L., Jalas, J., 1968. Vegetation zones and their sections in northwestern Europe. Ann. Bot. Fennici. 5, 169-211.

Aksenov, D., Dobrynin, D., Dubinin, M., Egorov, A., Isaev, A., Karpachevskyy, M., Lestadius, L., Potapov, P., Purehovsky, A., Tyrybanova, A., Yaroshenko, A., 2002. Atlas of Russia’s intact forest landscapes. Global Forest Watch Russia, Moscow.

Andrén, H., 1997. Habitat fragmentation and changes in biodiversity. Ecol. Bull. 46, 171-181.

Angelstam, P., Andersson, L., 2001. Estimates of the needs for forest reserves in Sweden. Scand. J. For. Res. 3, 38-51.

Angelstam, P., Anufriev, V., Balciauskas, L., Blagovidov, A., Borgegård, S-O., Hodge, S., Majewski, P., Ponomarenko, S., Shvarts, E., Tishkov, A., Tomialojc, L., Wesolowski, T., 1997. Biodiversity and sustainable forestry in European forests - how west and east can learn from each other. Wildlife Soc. Bull. 25(1), 38-48. 
Angelstam, P., Mikusiński, G., Rönnbäck, B.-I., Östman, A., Lazdinis, M., Roberge, J.-M., Arnberg, W., Olsson, J., 2003. Two-dimensional gap analysis: a tool for efficient conservation planning and biodiversity policy implementation. Ambio. 32 (8), 527-534.

Angelstam, P., Bergman, P., 2004. Assessing actual landscapes for the maintenance of forest biodiversity - a pilot study using forest management data. Ecol. Bull. 51, 413-425.

Angelstam, P., Boutin, S., Schmiegelow, F., Villard, M.-A., Drapeau, P., Host, G., Innes, J., Isachenko, G., Kuuluvainen, M., Mönkkönen, M., Niemelä, J., Niemi, G., Roberge, J.-M., Spence, J., Stone, D., $2004 a$. Targets for boreal forest biodiversity conservation - a rationale for macroecological research and adaptive management. Ecol. Bull. 51, 487-509.

Angelstam, P., Roberge, J.-M., Lõhmus, A., Bergmanis, M., Brazaitis, G., Dönz-Breuss, M., Edenius, L., Kosinski, Z., Kurlavicius, P., Lārmanis, V., Lūkins, M., Mikusinski, G., Račinskis, E., Strazds, M., Tryjanowski, P., 2004b. Habitat modelling as a tool for landscape-scale conservation - a review of parameters for focal forest birds. Ecol. Bull. 51, 427-453.

Angelstam, P., Dönz-Breuss, M., Roberge, J.-M. 2004c. Targets and tools for the maintenance of forest biodiversity - an introduction. Ecol. Bull. 51, 11-24.

Angelstam, P., Roberge, J.-M., Ek, T., Laestadius, L. 2005. Data and tools for conservation, management, and restoration of forest ecosystems at multiple scales. - In: Stanturf, J.A. and Madsen, P. (Eds). Restoration of boreal and temperate forests. CRC Press, Boca Raton, FL, 269-283.

Angelstam, P., Andersson, K., Axelsson, R., Elbakidze, M., Jonsson, B.-G., Roberge, J.-M. 2011. Protecting forest areas for biodiversity in Sweden 1991-2010: policy implementation process and outcomes on the ground. Silva Fennica, in press.

Anon., 1996. FSC - breaking borders. FSC certification and harmonization of standards in the Baltic region. FSC-SECR-0024.

Anon., 1997. The Last Frontier Forests: Ecosystems and Economies on the Edge. World Resources Institute.

Anon., 2001. National strategy for biodiversity conservation. Ministry of Nature resources of the Russian Federation, Moscow.

Anon., 2005. Recommendations for final fallings in pristine forests with securing the ecological forest value in Komi Republic. Forest Agency of Komi Republic, Ministry of Natural Resources of the Russian Federation.

Anon., 2008a. Forest management regalement of Priluzje lesnichestvo. Committee of Forestry, Komi Republic (In Russian)

Anon., 2008b. Russian National FSC standard. Russian FSC National Initiative.

Anon., 2009. Swedish FSC standard for Forest Certification. Board of FSC Sweden.

Auld, G., Gulbrandsen, L., McDermott, C., 2008. Certification schemes and the impacts of forests and forestry. Annu. Rev. Env. Resour. 33, 9.1 - 9.25.

Aune, K., Jonsson, B.-J., Moen, J., 2005. Isolation and edge effects among woodland key habitats in Sweden: Is forest policy promoting fragmentation? Biol. Conserv. 124, 89-95.

Bass, S., Thornber, K., Markopoulos, M., Roberts, S., Grieg-Gran, M., 2001. Certification’s impacts on forests, stakeholders and supply chains. Instruments for Sustainable Private Sector Forestry Series. International Institute of Environment and Development, London, UK.

Belovsky, G., 1987. Extinction models and mammalian persistence, in: Soulé, M. (Ed.) Viable populations for conservation, Cambridge University Press, Cambridge, pp. 35- 57.

Bennett, E.I., 2000. Timber certification: where is the voice of the biologist? Conserv. Biol. 14, 921-923.

Biedermann, R., 2003. Body size and area-incidence relationships: is there a general pattern? Global Ecol. Biogeogr. 12, 381-387.

Boström, M. 2002. Skogen Märks - Hur svensk skogscertifiering kom till och dess konsekvenser. SCOPE 20023, Stockholm.

Brown, N., R., Noss, D., Diamond, Myers, M., 2001. Conservation biology and forest certification: working together toward ecological sustainability. J. Forest. August, 18-25.

Burnett, C., Fall, A., Tomppo, E., Kalliola, R., 2003. Monitoring current status of and trends in boreal forest land use in Russian Karelia. Conserv. Ecol. 7(2), 8-12.

Cabarle, B., Brown, N., Cesareo, K., 2000. Integrating protected areas, plantations, and certification. J. Sustain. Forest. 21 (4), 15-34.

Carlson, M., Wells, J., Roberts, D. 2009. The carbon the world forgot: conserving the capacity of Canada's boreal forests region to mitigate and adapt to climate change. Boreal Songbird Initiative. Canada.

Cashore, B., Auld, G., Newsom, D., 2003. Forest certification (eco-labelling) programs and their policymaking authority: explaining divergence among North America and European case studies. Forest Pol. Econ. 5, 225-247. 
Cashore, B., van Kooten, C., Vertinsky, I., Auld, G., Affolderbach, J., 2005. Private or self-regulation? A comparative study of forest certification choices in Canada, the United States and Germany. Forest Pol. Econ. 7, 53-69.

Dise, N., 2009. Peatland response to global change. Science. 326, 810-811.

Edenius, L., Sjöberg, K., 1997. Distribution of birds in natural landscape mosaics of old-growth forests in northern Sweden, relations to habitat area and landscape context. Ecography. 20, 425-431.

Ek, I. 1995. Skinnskattebergs revir. Hultebo tryckeri AB, Skinnskatteberg (In Swedish)

Elbakidze, M., Angelstam, P., Axelsson, R., 2008. Sustainable forest management as an approach to regional development in the Russian Federation: state and trends in Kovdozersky Model Forest in the Barents region. Scand. J. Forest Res. 22, 568-581.

Elbakidze, M., Angelstam, P., 2008. Model Forest in the North West of the Russian Federation: view from outside. Ustoychivoe lesopolzovanie. 1 (17), 39-47 (In Russian)

Elbakidze, M., Angelstam, P., Sandström, C., Axelsson, R., 2010. Multi-stakeholder collaboration in Russian and Swedish Model Forest initiatives: adaptive governance towards sustainable forest management? Ecol. Soc. 15 (2): 14.

Eriksson, S., Hammer, M., 2006. The challenge of combining timber production and biodiversity conservation for long-term ecosystem functioning - a case study of Swedish boreal forestry. Forest Ecol. Manag. 237, 208-217.

Esseen, P.-A., Renhorn, K.-E., 1998. Edge effects on an epiphytic lichen in fragmented forests. Conser. Biol. 126, 1307-1317.

Fahrig, L., 2002. Effect of habitat fragmentation on the extinction threshold: a synthesis. Ecol. Appl. 12, 346-353.

Folke, C., Carpenter, S., Walker, B., Scheffer, M., Elmqvist, T., Gunderson, L., Holling, C. S., 2004. Regime shifts, resilience, and biodiversity in ecosystem management. Annual Rev. Ecol. Evolution Systematics. 35, 557-581.

Ghazoul, J., 2000. Barriers to biodiversity conservation in forest certification. Conserv. Biol. 15 (2), 315317.

Gulbrandsen, L., 2005. The effectiveness of non-state governance schemes: a comparative study of forest certification in Norway and Sweden. Int. Environ. Agreem. 5, 125-149.

Gulisson, R., 2003. Does forest certification conserve biodiversity? Oryx. 37 (2), 154-165.

Gustafsson, L., 2002. Presence and abundance of red-listed plan species in Swedish forests. Conserv. Biol. 16 (2), 377-388

Guynn, D., Guynn, S., Layton, P., Wigley T., 2004. Biodiversity metrics in sustainable forestry certification programs. J. Forest. April/May, 46-52.

Hannah, L., Carr, J. L. \& Lankerani, A. 1995. Human disturbance and natural habitat: a biome level analysis of a global data set. Biodiv. Conserv. 4, 128-155.

Hansen, M., Stehman, S., Potapov, P., 2010. Quantification of global gross forest cover loss. Proceedings of the National Academy of Scinces of the USA. 107 (19), 8650-8655.

Hanski, I., Moilanen, A., Gyllenberg, M., 1996. Minimum viable metapopulation size. Am. Nat. 147, 527541.

Hanski, I., 2000. Extinction debt and species credit in boreal forests: modelling the consequences of different approaches to biodiversity conservation. Ann. Zool. Fennici. 37, 271-280.

Hess, G., King, T., 2002. Planning open spaces for wildlife. I. Selecting focal species using a Delphi survey approach. Landscape Urban Plan. 58, 25-40.

Hirzel, A. H., Helfer, V., Metral, F., 2001. Assessing habitat suitability models with a virtual species. Ecol. Model. 145, 111-121.

Hysing, E., Olsson, J., 2005. Sustainability through good advice? Assessing the governance of Swedish forest biodiversity. Environ. Polit. 14(4), 510-526.

Jansson, G., Andrén, H., 2003. Habitat composition and bird diversity in managed boreal forests. Scand. J. Forest Res. 18, 225-236.

Jansson, G., Angelstam, P., 1999. Thresholds of landscape composition for the presence of the long-tailed tit in a boreal landscape. Landscape Ecol. 14, 283-290.

Kuuluvainen, T., 2009. Forest management and biodiversity conservation based on natural ecosystem dynamics in northern Europe: the complexity challenge. Ambio. 38(6),309 -315.

Lambeck, R.J., 1997. Focal species: a multi-species umbrella for nature conservation. Conserv. Biol. 11 (4), 849-856.

Larsson, T.-B., Angelstam, P., Balent, G., Barbati, A., Bijlsma, R.-J., Boncina, A., Bradshaw, R., Bücking, W., Ciancio, O., Corona, P., Diaci, J., Dias, S., Ellenberg, H., Manuel Fernandes, F, FernandezGonzalez, F., Ferris, R., Frank, G., Friis Møller, P., Giller, P.S., Gustafsson, L., Halbritter, K., Hall, S., 
Hansson, L., Innes, J., Jactel, H., Keannel Dobbertin, M., Klein, M., Marchetti, M., Mohren, F., Niemelä, P., O’Halloran, J., Rametsteiner, E., Rego, F., Scheidegger, C., Scotti, R., Sjöberg, K., Spanos, I., Spanos, K., Standovar, T., Svensson, L., Tømmerås, B.Å., Trakolis, D., Uuttera, J., VanDenMeerschaut, D., Vanderkerkhove, K., Walsh, P.M., Watt, A.D., 2001. Biodiversity evaluation tools for European forests. Ecol. Bull 50.

Laurance, W., Yensen, E.,1991. Predicting the impacts of edge effects in fragmented habitats. Biol. Conserv. 55, 77-92.

Lehtinen, A.A., Donner-Amnell, J., Saether, B., 2004 Northern forest-industrial regimes in the age of globalization, Ashgate.

Linnell, J., Promberger, C., Boitani, L., Swenson, J. E., Breitenmoser, U., Andersen, R., 2005. The linkage between conservation strategies for large carnivores and biodiversity: the view from the "half-full" forests of Europe, in: Ray, J., Redford, K., Steneck, R., Berger, J. (Eds.), Large Carnivores and Biodiversity Conservation , Island Press, Washington, DC., pp. 381-399.

Konsult, LRF., 1999. Instruktion för naturvårdsanpassad skogsbruksplanläggning. Version 2.3. LRF Skogsbyrån

Manton, M.G., Angelstam, P., Mikusiński, G., 2005. Modelling habitat suitability for deciduous forest focal species - a sensitivity analysis using different satellite land cover data. Landscape Ecol. 20, 827-839.

Mayer, A., Kauppi, P., Angelstam, P. Zhang, Y., Tikka, P., 2005. Importing timber, exporting ecological impact. Science. 308, 59-60.

McNab, B.K., 1963. Bioenergetics and the determination of home range size. Am. Nat. 97, 133-140.

McNeely, J.A., 1994. Lessons from the past: forests and biodiversity. Biodiv. Conser. 3, 3-20.

Meffe, G., Carroll, C., 1994. Principles of conservation biology. Sinauer, Sunderland, Massachusetts.

Menges, E.S., 1991. The application of minimum viable population theory to plants, in: Falk, D., Holsinger, K. (Eds), Genetics and conservation of rare plants. Oxford University Press, New York, pp. 45-61.

Mikusiński, G., Edenius, L., 2006. Assessment of spatial functionality of old forest in Sweden as habitat for virtual species. Scand. J. Forest Res. 21 (1), 73-83.

Minor, E., Lookingbill, T., 2010. A multiscale network analysis of protected-area connectivity for mammals in the United State. Conserv Biol. 24 (6), 1549-1558.

Moen, J., Jonsson, B.G., 2003. Edge effects on liverworts and lichens in forest patches in a mosaic of boreal forest and wetland. Conserv. Biol. 17, 380-388.

Naturvårdsverket and Skogsstyrelsen, 2005. Nationell strategi för formellt skydd av skog. Naturvårdsverket, Stockholm and Skogsstyrelsen, Jönköping.

Nilsson, C., Götmark, F. 1992. Protected areas in Sweden: is natural variety adequately represented? Conserv. Biol. 6, 232-242.

Nilsson, S., Niklasson, M., Hedin, J., Eliasson, P., Ljungberg, H., 2005. Biodiversity and sustainable forestry in changing landscapes - principles and Southern Sweden as an example. J. Sustain. Forest. 21, $11-43$.

Noss, R. F., 1990. Indicators for monitoring biodiversity: a hierarchical approach. Conserv. Biol. 4, 355364.

Ostapowicz, K., Vogt, P., Ritters, K., Kozak, J., Estreguil, C., 2008. Impact of scale on morphological spatial pattern of forest. Landscape Ecol. 23, 1107-1117.

Poiani, K., Richter, B., Anderson, M., Richter, H., 2000. Biodiversity conservation at multiple scales: functional sites, landscapes, and networks. BioScience. 50 (2), 133-146.

Potapov, P., Yaroshenko, A., Turubanova, S., Dubinin, M., Laestadius, L., Thies, Ch., Aksenov, D., Egorov, A., Yesipova, E., Glushkov, I., Karpachevskiy, M., Kostikova, A., Manisha, A., Tsybikova, E., Zhuravleva, I., 2008. Mapping the World’s Intact Forest Landscapes by Remote Sensing. Ecology and Society. 13 (2), 51.

Rametsteiner, E., Simula, M., 2003. Forest certification - an instrument to promote sustainable forest management? J. Environ. Manage. 67, 87-98.

Roberge, J.-M., Angelstam, P., 2004. Usefulness of the umbrella species concept as a conservation tool. Conserv. Biol. 18(1), 76-85.

Rockström, J., Steffen, W., Noone, K., Persson, E., Chapin III, F., Lambin, E., Lenton, T., Scheffer, M., Folke, C., Schellnhuber, H., Nykvist, B., De Wit, C., Hughes, T., van der Leeuw, S., Rodhe, H., Surlin, S., Snyder, P., Costanza, R., Svedin, U., Falkenmark, M., Karlberg, L., Corell, R., Fabry, V., Hansen, J., Walker, B., Liverman, D., Richardson, K., Crutzen, P., Foley, J., 2009. Planetary boundaries: exploring the safe operating space for humanity. Ecol. Soc. 14(2), 32.

Shorohova, E, Tetioukhin, S. 2004. Natural disturbances and the amount of large trees, deciduous trees and coarse woody debris in the forests of Novgorod Region, Russia. Ecological Bulletins 51, 137-147.

Soille, P., Vogt, P., 2009. Morphological segmentation of binary patterns. Pattern Recognition Letters. 30, 456-459. 
SOU., 1997. Skydd av skog. Behov och kostnader. Rapport 1997:98. Miljövårdsberedningen.

Store, R., Jokimäki, J., 2003. A GIS-based multi-scale approach to habitat suitability modelling. Ecol. Model. 169, 1-15.

Svancara, L.K., Brannon, R., Scott, J.M., Groves, C.R., Noss, R.F. \& Pressey, R.L. 2005. Policy-driven versus evidence-based conservation: a review of political targets and biological needs. BioScience 55(11): 989-995.

Swedish Forestry Act. On: http://www.svo.se/episerver4/templates/SNormalPage.aspx?id=11303

Taylor, P., Fahrig, L., Henein, K., Merriam, G., 1993. Connectivity is a vital element of landscape structure. Oikos. 68 (3), 571-572.

Taylor P., Fahrig, L., With, K., 2006. Landscape connectivity: a return to the basics, in Crooks, K., Sanjayan, M. (Eds), Connectivity conservation. Cambridge University Press, pp. 29-43.

Villard, M.-A, Jonsson, B.G., 2009. Setting conservation targets for managed forest landscapes. Cambridge University Press, Cambridge.

Vogt, P., Riitters, K., Estreguil, C., Kozak, J., Wade, T., Wickham, J., 2007a. Mapping spatial patterns with morphological image processing. Landscape Ecol. 22, 171-177.

Vogt, P., Riitters, K., Iwanowski, M., Estreguil, C., Kozak, J., Soille, P., 2007b. Mapping landscape corridors. Ecol. Indic. 7 (2), 481-488.

Vogt, P., Ferrari, J., Lookingbill, T., Gardner, R., Riitters, K., Ostapowicz, K., 2009. Mapping potential functional connectivity. Ecol. Indic. 9, 64-71.

Wickham, J., K., Riitters, T., Wadea, P., Vogt., 2010. A national assessment of green infrastructure and change for the conterminous United States using morphological image processing. Landscape Urban Plan. 94, 186-195.

Wiens, J.A, Milne, B.T. 1989. Scaling of 'landscapes' in landscape ecology, or, landscape ecology from a beetle's perspective. Landscape Ecol.. 3(2), 87-96.

With, K., Gardner, R., Turner, G., 1997. Landscape connectivity and population distribution in heterogeneous environments. Oikos. 78, 151-169.

With, K., King, A., 1999. Extinction thresholds for species in fractal landscapes. Conserv. Biol. 13, 314326.

Yaroshenko, A. , Potapov, P. , Turubanova, S., 2001. The intact forest landscapes of northern European Russia. Greenpeace Russia and the Global Forest Watch, Moscow.

Öckinger, E., Nilsson, S., 2010. Local population extinction and vitality of an epiphytic lichenin fragmented old-growth forest. Ecology. 91(7), 2100-2109

http://www.fsc.org/vision_mission.html

http://www.fscoax.org/principal.htm

http://www.fsc.org/certification.html

www.fsc.org/facts-figures.html

www.sveaskog.se/en/Forestry-and-Environment/Nature-conservation 


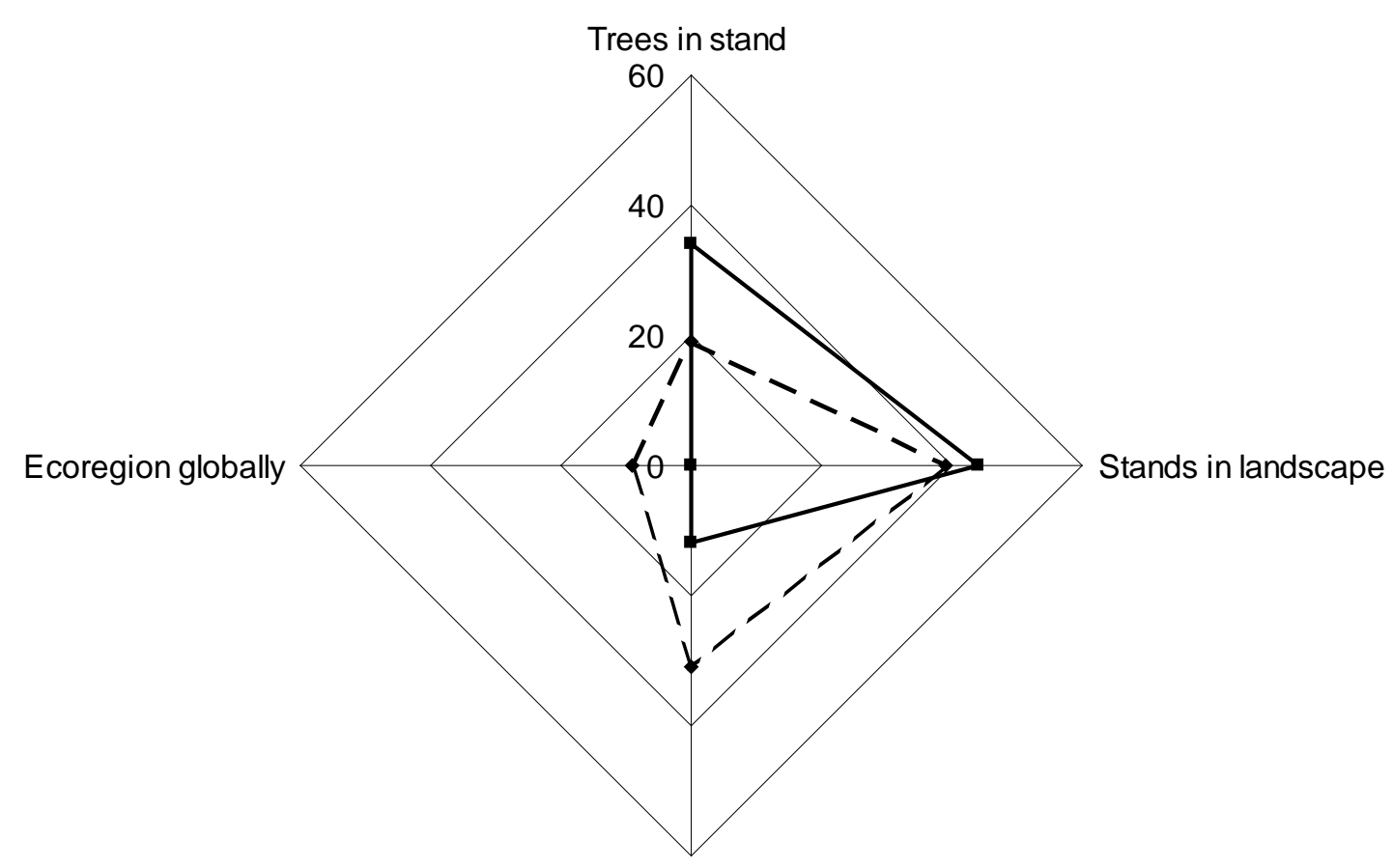

Landscape in ecoregion

$\multimap-$ The Russian FSC standard $\longrightarrow$ The Swedish FSC standard

Figure 1. Indicators for biodiversity conservation on different spatial scales of forest management aimed at maintaining and protecting forest biodiversity in the national FSC standards in the Russian Federation and Sweden (a number along lines shows a total number of indicators related to biodiversity conservation on the different spatial scale) 


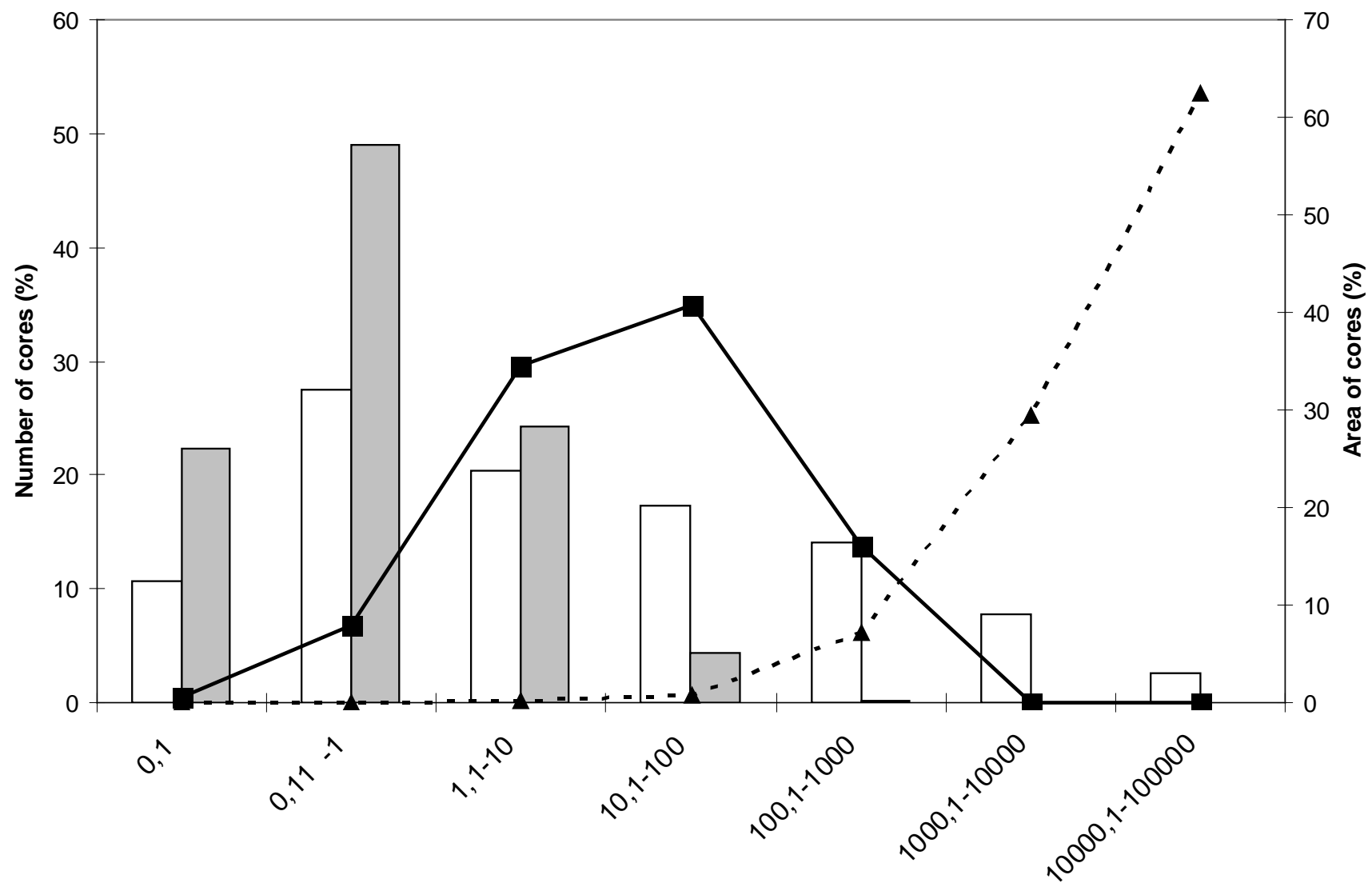

Core size (ha) (edge width is $25 \mathrm{~m}$ )

$\square \%$ of total number of cores(Priluzje) $\square \%$ of total number of cores (Sveaskog)

- - - - - \% of total area of cores (Priluzje) _ _ _ 


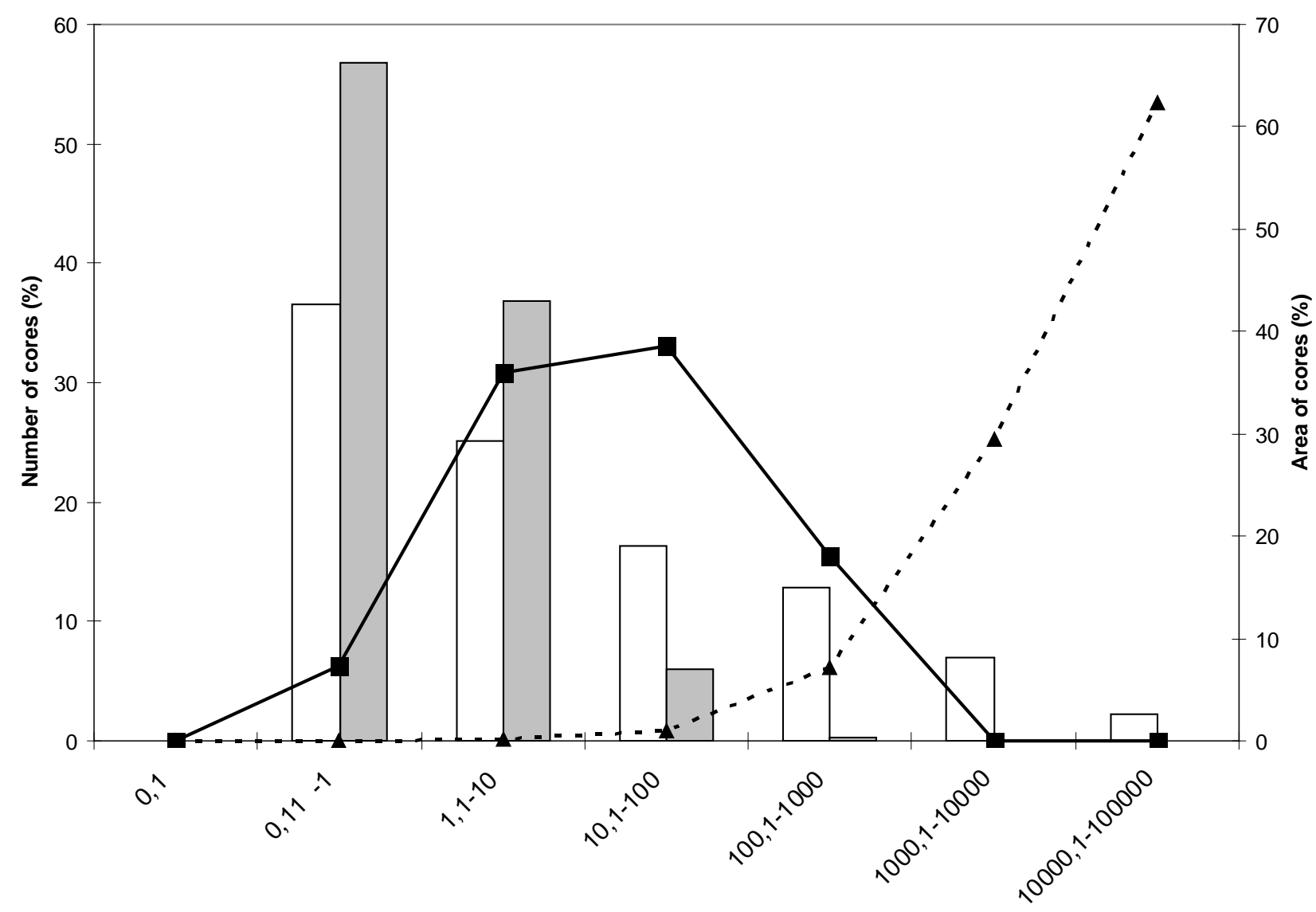

B.

Core size (ha) (edge width is $50 \mathrm{~m}$ )

$\square \%$ of total number of cores(Priluzje)
- - $-\%$ of total area of cores (Priluzje)

Figure 2 (A, B). Distribution of area and size of core areas of formally and voluntarily set-aside forests in the Priluzje state forest management unit and the Bergslagen holding of Sveaskog Co with an edge widths of $25 \mathrm{~m}$ (A) and $50 \mathrm{~m}$ (B). 


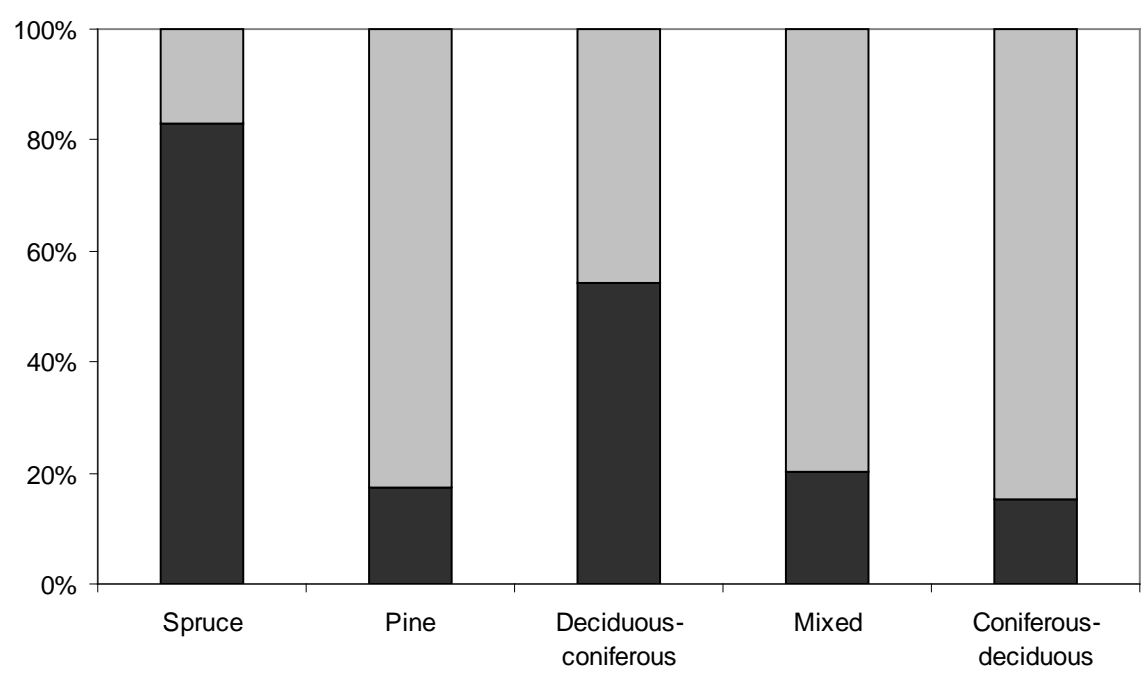

$\square$ Area of old cores $\square$ Area of all cores

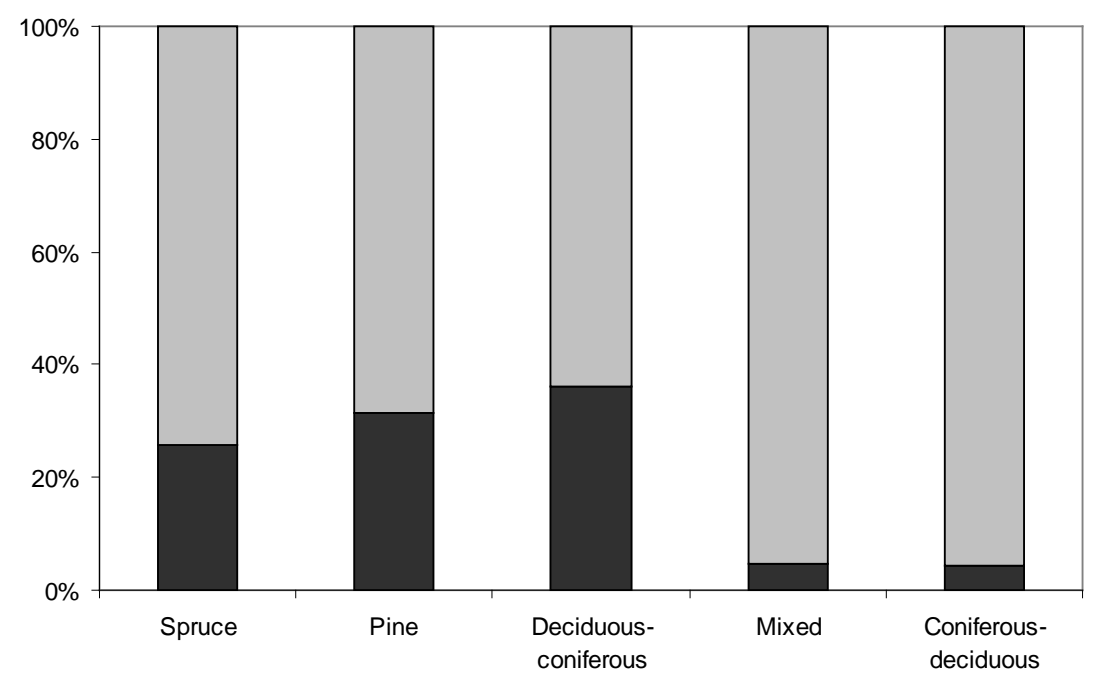

- Area of old cores (\%) — Area of all cores (\%)

A.

B.

Figure 3 (A, B). Area of old cores (cores of over-mature and old forests) as a proportion to the total area of all cores of different forest types (25 m of edge size) in the Priluzje state forest management unit in the Russian Federation (A) and the Bergslagen holding of Sveaskog CO. in Sweden (B). 


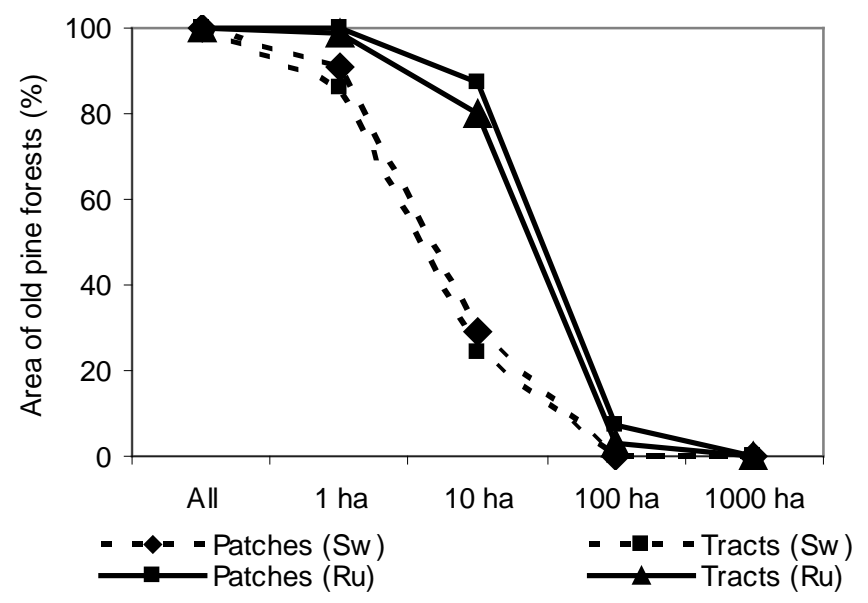

A.

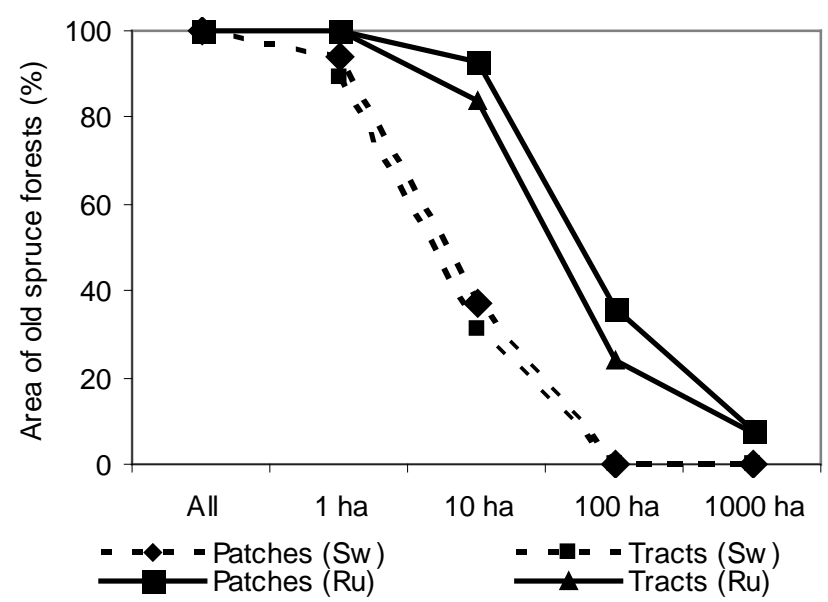

B.

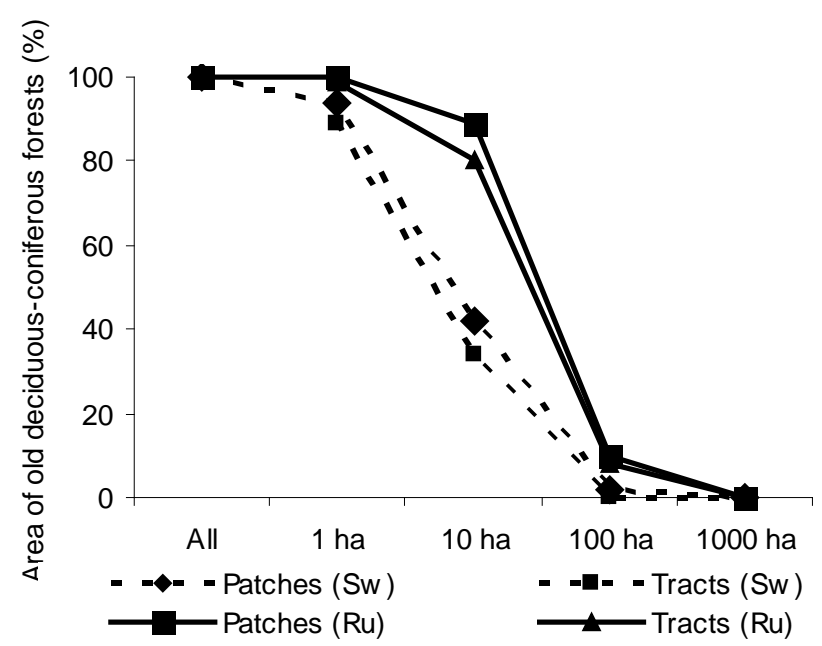

C. 


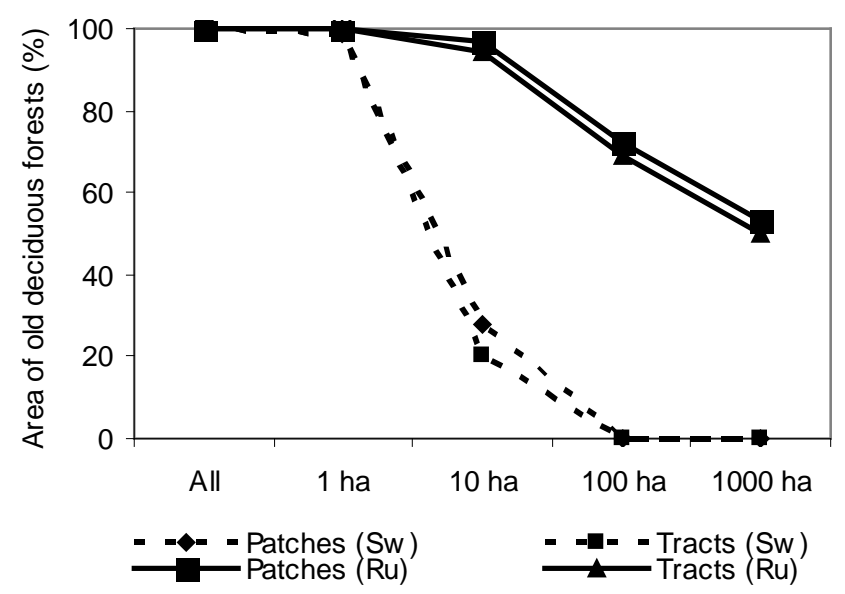

D.

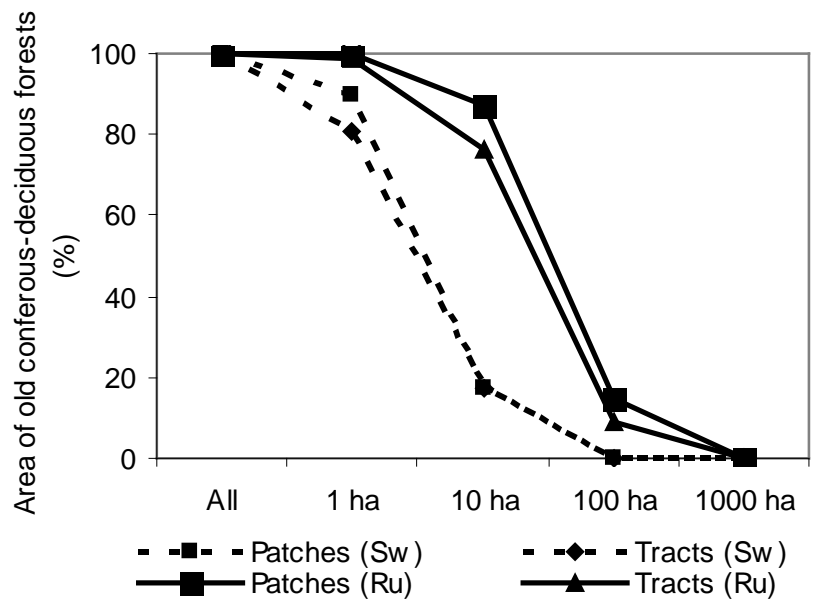

E.

Figure 4 (A, B, C, D, E). Results from modelling of habitat network functionality for over-mature and old set-aside forests in Bergslagen (Sweden) and Priluzje (Russia) for: pine (A), spruce (B), deciduousconiferous (C), deciduous (D) and coniferous-deciduous (E) forests. The graphs show the proportion in percent of all 25x25 pixels which are located in sufficiently large stands for the focal species, and in functional tracts of habitat. 


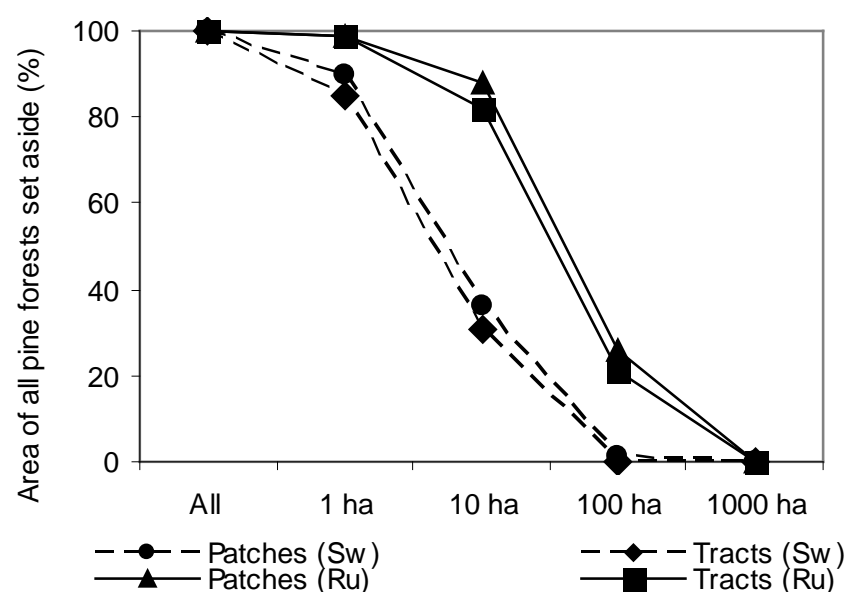

A.

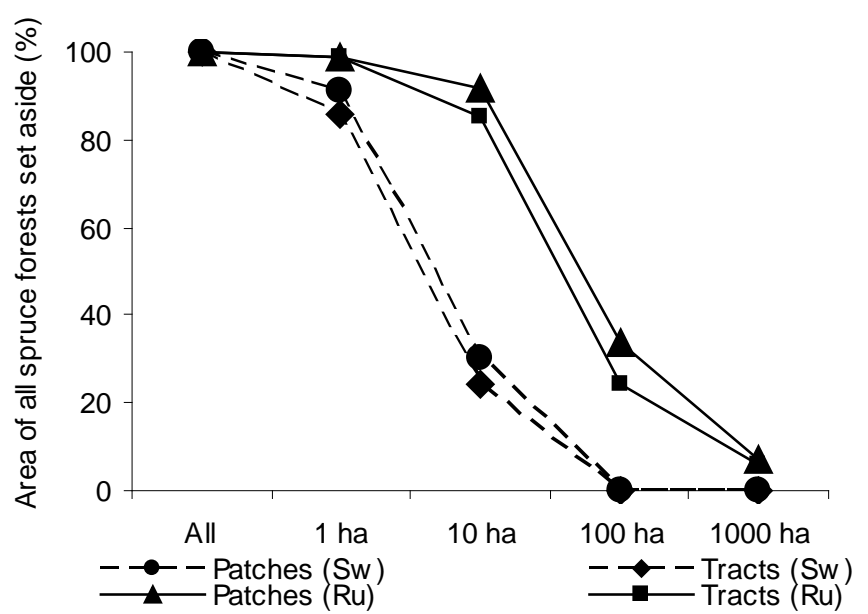

B

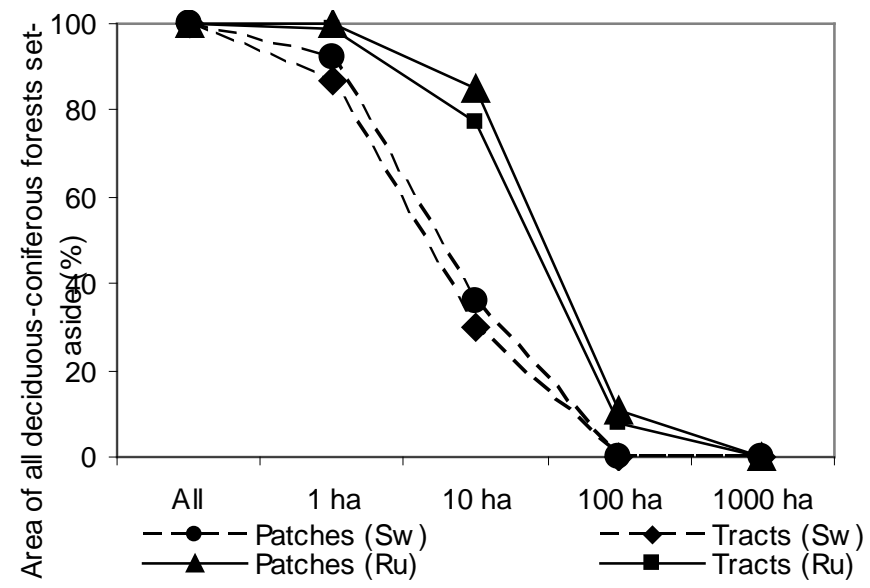

C. 


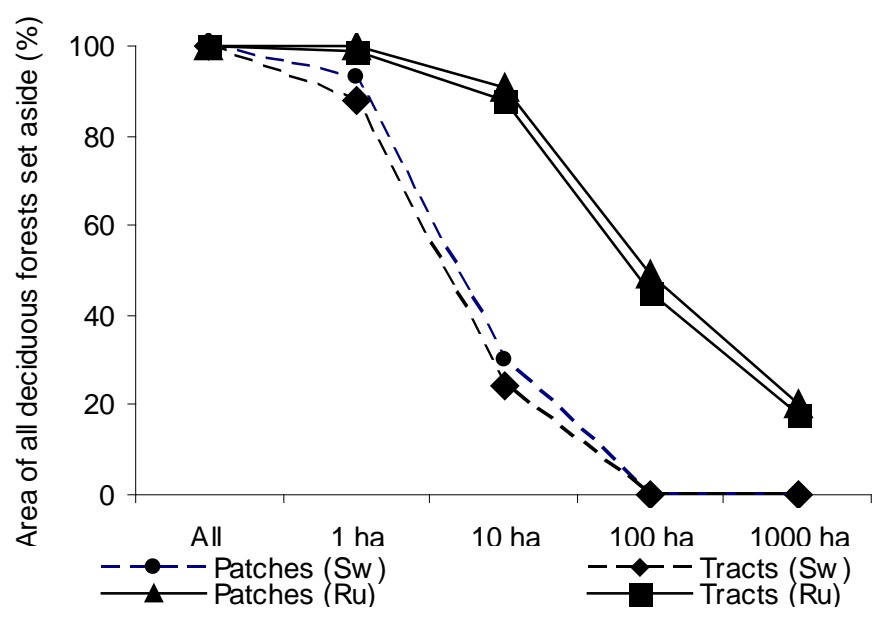

D.

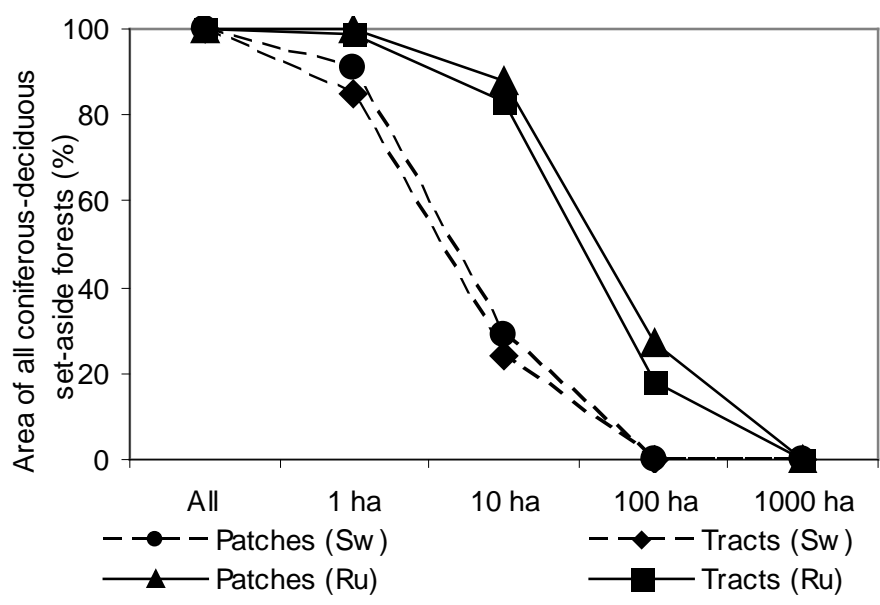

E.

Figure 5 (A, B, C, D, E). Results from modelling of habitat network functionality for all forests in Bergslagen (Sweden) and Priluzje (Russia) in the future assuming that set-asides will neither be harvested nor subject to stand-replacing disturbance for pine (A), spruce (B), deciduous-coniferous (C), deciduous (D) and coniferous-deciduous (E) forests. The graphs show the proportion in percent of all $25 \times 25$ pixels which are located in sufficiently large stands for the focal species, and in functional tracts of habitat. 
Table 1 Definitions of Morphological spatial pattern analysis (MSPA) classes. The foreground is pixels of set-aside forests and the background is pixels representing the production forest and all other land cover types (Soille and Vogt, 2009).

\begin{tabular}{|c|c|}
\hline Class & Explanation \\
\hline Core & $\begin{array}{l}\text { Foreground pixels surrounded on all sides by foreground pixels and greater than the speci- } \\
\text { fied edge width distance from the background. }\end{array}$ \\
\hline Islet & Foreground pixels that do not contain core. Islet is the only unconnected class. \\
\hline \multirow[t]{2}{*}{ Perforation } & $\begin{array}{l}\text { Pixels that form the transition zone between the background and foreground for interior re- } \\
\text { gions of the foreground. The pixels forming the inner edge would be classified as perfora- } \\
\text { tions, whereas those forming the outer edge would be classified as edge. }\end{array}$ \\
\hline & Pixels that form the transition zone between the foreground and background. \\
\hline Edge & Foreground pixels that connect the area of core to itself. \\
\hline Loop & Foreground pixels that connect two or more disjunct areas of core. \\
\hline Bridge & $\begin{array}{l}\text { Foreground pixels that extend from the area of core, but do not connect to another area of } \\
\text { core. }\end{array}$ \\
\hline Branch & \\
\hline
\end{tabular}


Table 2 Classification of forest stands based on their age and tree species composition. The forest stands were divided based on the main tree species (Scots pine, Norway spruce, coniferous, deciduous, and mixed deciduous and coniferous) and on their age (young, middle age, mature, over-mature and old forest stands). Each cell shows the possible diversity of forest stand categories and an identification code based on combination of tree species and age classes.

\begin{tabular}{lllllll}
\hline $\begin{array}{l}\text { Forest stand based on the main } \\
\text { tree species }\end{array}$ & \multicolumn{5}{l}{ Forest stands based on age class in years } \\
\cline { 3 - 7 } & $\begin{array}{l}10-40 \\
\text { (young) }\end{array}$ & $\begin{array}{l}41-70 \\
\text { (middle age) }\end{array}$ & $\begin{array}{l}71-110 \\
\text { (mature) }\end{array}$ & $\begin{array}{l}111-140 \\
\text { (over ma- } \\
\text { ture }\end{array}$ & $\begin{array}{l}141-\ldots \\
\text { (old) }\end{array}$ \\
\hline Scots pine & $>70 \%$ pine & 11 & 12 & 13 & 14 & 15 \\
\hline Norway spruce & $>70 \%$ spruce & 21 & 22 & 23 & 24 & 25 \\
\hline $\begin{array}{l}\text { Deciduous- } \\
\text { coniferous }\end{array}$ & $>70 \%$ pine & 31 & 32 & 33 & 34 & 35 \\
\hline Deciduous & $\begin{array}{l}>70 \% \text { de- } \\
\text { and spruce }\end{array}$ & 41 & 42 & 43 & 44 & 45 \\
\hline $\begin{array}{l}\text { Coniferous- } \\
\text { deciduous }\end{array}$ & $\begin{array}{l}31-49 \% \text { de- } \\
\text { ciduous }\end{array}$ & 51 & 52 & & & \\
\hline
\end{tabular}


Table 3 Examples of indicators in the Swedish and Russian FSC standards related to biodiversity conservation which require actions on different spatial scales such as trees in a stand; stands in a landscape; a landscape scale; an ecoregion.

\begin{tabular}{|c|c|c|}
\hline $\begin{array}{l}\text { Spatial scale for biodiversity conserva- } \\
\text { tion in managed forests }\end{array}$ & Swedish FSC standard & Russian FSC standard \\
\hline Trees in a stand & $\begin{array}{l}\text { Managers shall retain and safeguard, as part of all forestry } \\
\text { measures, all trees with high biodiversity values: aber- } \\
\text { rant, particularly large and/or old trees, large trees with } \\
\text { notably wide girth and thick-branched and/or flat crowns, } \\
\text { large, previously solitary growing spruces on pasture } \\
\text { land, large aspen and alders where these do not occur in } \\
\text { abundance, in stands dominated by conifers, arborescent } \\
\text { goat willow, mountain ash, whitebeam, maple, lime, bird- } \\
\text { cherry, wild cherry and large hazel in stands dominated } \\
\text { by conifers, large junipers, trees with distinct open bole } \\
\text { fire scars, hollow trees and trees with stick nests of birds } \\
\text { of prey, trees with evident features of cultural importance, } \\
\text { individual or small groups of valuable broad-leaf trees in } \\
\text { the boreal forest landscape (6.3.18) }\end{array}$ & $\begin{array}{l}\text { The following wind throw resistant key stand elements (re- } \\
\text { sidual trees and their groups) shall be completely or partly } \\
\text { left during timber harvesting: old trees of non-target spe- } \\
\text { cies; large trees with holes; trees with large bird nests; vet- } \\
\text { eran trees whose age noticeably exceeds the average age of } \\
\text { the main canopy; and tree species considered to be rare in } \\
\text { this area (6.3.9) }\end{array}$ \\
\hline Stands in a landscape & $\begin{array}{l}\text { Managers shall exempt a minimum of } 5 \% \text { of the produc- } \\
\text { tive forest land area from measurements other than man- } \\
\text { agement required to maintain or promote biodiversity } \\
\text { conditioned by natural processes or traditional land use } \\
\text { practices (6.4.1) }\end{array}$ & $\begin{array}{l}\text { Protective zones shall be established along all water } \\
\text { streams, lakes and bogs (high moors) (5.5.1) }\end{array}$ \\
\hline Landscape scale & $\begin{array}{l}\text { Managers of major holdings shall plan forest manage- } \\
\text { ment with the aim of achieving an ecological balanced } \\
\text { age distribution in the landscape, with special attention to } \\
\text { the proportion of older forest in landscapes where there is } \\
\text { a deficit of such forest (6.1.1) }\end{array}$ & $\begin{array}{l}\text { The enterprise shall establish a network of representative } \\
\text { samples of existing ecosystems within the forest area being } \\
\text { certified, which provides preservation of the diversity pf } \\
\text { landscapes, ecosystems, habitat types and local flora and } \\
\text { fauna (6.4.1) }\end{array}$ \\
\hline Eco-region & Not found & $\begin{array}{l}\text { Large forest landscapes minimally disturbed by human } \\
\text { agency shall be conserved (9.3.3) }\end{array}$ \\
\hline
\end{tabular}


Table 4 Area and types of formally and voluntary set-aside forests in the Bergslagen holding of Sveaskog Co. (Sweden) and the Priluzje state forest management unit (Russia)

\begin{tabular}{|c|c|c|c|}
\hline & $\begin{array}{l}\text { Forests set aside for biodiversity conser- } \\
\text { vation }\end{array}$ & $\begin{array}{l}\text { Area (ha) } / \% \\
\text { from total for- } \\
\text { ested land }\end{array}$ & Legal framework \\
\hline \multicolumn{4}{|c|}{ Bergslagen holding, Sveaskog Co. (Sweden) } \\
\hline $\begin{array}{l}\text { Formally set- } \\
\text { aside forests }\end{array}$ & $\begin{array}{l}\text { Natura } 2000 \\
\text { Nature reserve } \\
\text { Nature of national interest }\end{array}$ & $\begin{array}{l}\text { 16,763 ha, } \\
3.3 \%\end{array}$ & $\begin{array}{l}\text { EU Bird Directive, EU Habi- } \\
\text { tat Directive, } \\
\text { Environmental Code }\end{array}$ \\
\hline $\begin{array}{l}\text { Voluntarily } \\
\text { set-aside } \\
\text { forests }\end{array}$ & NO, NS and PF forest classes & $\begin{array}{l}\text { 40,784 ha, } \\
8.8 \%^{\dagger}\end{array}$ & $\begin{array}{l}\text { Swedish Forestry Act } \\
\text { Swedish National FSC stan- } \\
\text { dard }\end{array}$ \\
\hline \multicolumn{4}{|c|}{ Total area of forests set aside $\quad 57,547$ ha, or $12.4 \%$ of total area of forested land } \\
\hline \multicolumn{4}{|c|}{ Priluzje state forest management unit (Russia) } \\
\hline $\begin{array}{l}\text { Formally set- } \\
\text { aside forests }\end{array}$ & $\begin{array}{l}\text { Forests with water protective functions } \\
\text { along rivers and streams } \\
\text { Forests along roads } \\
\text { Forests along the spawning places } \\
\text { Nature reserves }\end{array}$ & $\begin{array}{l}\text { 91,369 ha, } \\
11.5 \%\end{array}$ & $\begin{array}{l}\text { Water Code 2006, } \\
\text { Forest Code 2007, } \\
\text { Law on Special Protected } \\
\text { Nature Territories (1995) }\end{array}$ \\
\hline $\begin{array}{l}\text { Voluntary } \\
\text { set-aside } \\
\text { forests }\end{array}$ & $\begin{array}{l}\text { Pristine forests (HCFV 2) } \\
\text { Forests with high social and cultural val- } \\
\text { ues for local people (HCVF } 5 \text { and 6) }\end{array}$ & $\begin{array}{l}82,609 \text { ha, } \\
10.4 \%\end{array}$ & $\begin{array}{l}\text { Russian National FSC stan- } \\
\text { dard }\end{array}$ \\
\hline Total area of $\mathrm{f}$ & 173,978 ha, or 21.9 & of total area of $f$ & ested land \\
\hline
\end{tabular}

\footnotetext{
${ }^{\dagger}$ This figure does not include the area occupied by a single tree or a small group of trees in the Bergslagen holding of Sveaskog Co.
} 
Table 5 Area of main pattern classes and forest types set aside for biodiversity conservation in Bergslagen holding of Sveaskog Co. (Sweden). Numbers in parentheses are percentages of each pattern class for each forest type.

\begin{tabular}{|c|c|c|c|c|c|c|c|c|c|c|c|c|}
\hline \multirow[b]{3}{*}{ Pattern class } & \multicolumn{2}{|l|}{ Spruce } & \multicolumn{2}{|l|}{ Pine } & \multicolumn{2}{|l|}{ Coniferous } & \multicolumn{2}{|c|}{ Coniferous-deciduous } & \multicolumn{2}{|l|}{ Deciduous } & \multirow{2}{*}{\multicolumn{2}{|c|}{$\begin{array}{l}\text { Pattern class (\% of forest } \\
\text { area) }\end{array}$}} \\
\hline & \multicolumn{2}{|l|}{ Edge width } & \multicolumn{2}{|c|}{ Edge width } & \multicolumn{2}{|l|}{ Edge width } & \multicolumn{2}{|l|}{ Edge width } & \multicolumn{2}{|l|}{ Edge width } & & \\
\hline & $25 \mathrm{~m}$ & $50 \mathrm{~m}$ & $25 \mathrm{~m}$ & $50 \mathrm{~m}$ & $25 \mathrm{~m}$ & $50 \mathrm{~m}$ & $25 \mathrm{~m}$ & $50 \mathrm{~m}$ & $25 \mathrm{~m}$ & $50 \mathrm{~m}$ & $25 \mathrm{~m}$ & $50 \mathrm{~m}$ \\
\hline Core & $\begin{array}{l}4557 \\
(7.1) \\
\end{array}$ & $\begin{array}{l}1533 \\
(2.4) \\
\end{array}$ & $\begin{array}{l}8888 \\
(14.0)\end{array}$ & $\begin{array}{l}3236 \\
(5.1) \\
\end{array}$ & $6328(9.9)$ & $2314(3.7)$ & $1664(2.6)$ & $\begin{array}{l}520 \\
(0.8)\end{array}$ & $1181(1.9)$ & $\begin{array}{l}337 \\
(0.5)\end{array}$ & 35.5 & 12.5 \\
\hline Islet & $1466(2.3)$ & $\begin{array}{l}5488 \\
(8.7) \\
\end{array}$ & $\begin{array}{l}2581 \\
(4.1) \\
\end{array}$ & $\begin{array}{l}9246 \\
(14.6)\end{array}$ & $1870(2.9)$ & $\begin{array}{l}6858 \\
(10.8)\end{array}$ & $\begin{array}{l}679 \\
(1.1) \\
\end{array}$ & $\begin{array}{l}2548 \\
(4.0) \\
\end{array}$ & $\begin{array}{l}823 \\
(1.3) \\
\end{array}$ & $\begin{array}{l}2706 \\
(4.3)\end{array}$ & 11.7 & 42.4 \\
\hline Perforation & $\begin{array}{l}7 \\
(\sim 0) \\
\end{array}$ & $\begin{array}{l}0 \\
(0) \\
\end{array}$ & $\begin{array}{l}62 \\
(0.1) \\
\end{array}$ & $\begin{array}{l}0 \\
(0) \\
\end{array}$ & $\begin{array}{l}34 \\
(\sim 0.1) \\
\end{array}$ & $\begin{array}{l}0 \\
(0) \\
\end{array}$ & $\begin{array}{l}0 \\
(0) \\
\end{array}$ & $\begin{array}{l}0 \\
(0) \\
\end{array}$ & $\begin{array}{l}4 \\
(\sim 0) \\
\end{array}$ & $\begin{array}{l}0 \\
(0) \\
\end{array}$ & 0.1 & 0 \\
\hline Edge & $4630(7.3)$ & $\begin{array}{l}3145 \\
(4.9) \\
\end{array}$ & $\begin{array}{l}7571 \\
(11.9)\end{array}$ & $\begin{array}{l}5318 \\
(8.4) \\
\end{array}$ & $5942(9.4)$ & $4106(6.5)$ & $1816(2.7)$ & $\begin{array}{l}1091 \\
(1.7)\end{array}$ & $1703(2.7)$ & $\begin{array}{l}810 \\
(1.3)\end{array}$ & 34.0 & 22.8 \\
\hline Loop & $\begin{array}{l}106 \\
(0.2)\end{array}$ & $\begin{array}{l}80 \\
(0.1)\end{array}$ & $\begin{array}{l}219 \\
(0.3)\end{array}$ & $\begin{array}{l}693 \\
(1.1)\end{array}$ & $\begin{array}{l}169 \\
(0.3)\end{array}$ & $\begin{array}{l}345 \\
(0.5)\end{array}$ & $\begin{array}{l}51 \\
(\sim 0,1)\end{array}$ & $\begin{array}{l}104 \\
(0.2)\end{array}$ & $\begin{array}{l}66 \\
(0,1)\end{array}$ & $\begin{array}{l}145 \\
(0.2)\end{array}$ & 0.9 & 2.1 \\
\hline Bridge & $\begin{array}{l}377 \\
(0.6)\end{array}$ & $\begin{array}{l}432 \\
(0.7)\end{array}$ & $\begin{array}{l}762 \\
(1.2)\end{array}$ & $\begin{array}{l}1156 \\
(1.8)\end{array}$ & $\begin{array}{l}525 \\
(0.8)\end{array}$ & $\begin{array}{l}690 \\
(1.1)\end{array}$ & $\begin{array}{l}161 \\
(0.3)\end{array}$ & $\begin{array}{l}156 \\
(0.2)\end{array}$ & $\begin{array}{l}223 \\
(0.4)\end{array}$ & $\begin{array}{c}145 \\
(0.2)\end{array}$ & 3.3 & 4.0 \\
\hline Branch & $1878(2.9)$ & $\begin{array}{l}2343 \\
(3.8)\end{array}$ & $\begin{array}{l}3033 \\
(4.8)\end{array}$ & $\begin{array}{l}3467 \\
(5.5)\end{array}$ & $2376(3.7)$ & $2931(4.6)$ & $\begin{array}{l}828 \\
(1.3)\end{array}$ & $\begin{array}{l}780 \\
(1.2)\end{array}$ & $\begin{array}{l}817 \\
(1.8)\end{array}$ & $\begin{array}{l}674 \\
(1.1)\end{array}$ & 14.5 & 16.2 \\
\hline $\begin{array}{l}\text { Total area of forest } \\
\text { type (ha and in \%) }\end{array}$ & $\begin{array}{l}13021 \\
(20.5)\end{array}$ & & $\begin{array}{l}23116 \\
(36.5)\end{array}$ & & $\begin{array}{l}17244 \\
(27.2)\end{array}$ & & $\begin{array}{l}5199 \\
(8.2)\end{array}$ & & $\begin{array}{l}4817 \\
(7.6)\end{array}$ & & & \\
\hline
\end{tabular}


Table 6 Area of main pattern classes and forest types set aside for biodiversity conservation in the Priluzje state forest management unit (Komi Republic, Russian Federation). Numbers in parentheses are percentages of each pattern class for each forest type.

\begin{tabular}{|c|c|c|c|c|c|c|c|c|c|c|c|c|}
\hline \multirow[b]{3}{*}{ Pattern class } & \multirow{2}{*}{\multicolumn{2}{|c|}{$\begin{array}{l}\text { Spruce forest } \\
\text { Edge width }\end{array}$}} & \multirow{2}{*}{\multicolumn{2}{|c|}{$\begin{array}{l}\text { Pine } \\
\text { Edge width } \\
\end{array}$}} & \multirow{2}{*}{\multicolumn{2}{|c|}{$\begin{array}{l}\text { Coniferous } \\
\text { Edge width } \\
\end{array}$}} & \multirow{2}{*}{\multicolumn{2}{|c|}{$\begin{array}{l}\text { Coniferous-deciduous } \\
\text { Edge width }\end{array}$}} & \multirow{2}{*}{\multicolumn{2}{|c|}{$\begin{array}{l}\text { Deciduous forest } \\
\text { Edge width }\end{array}$}} & \multirow{2}{*}{\multicolumn{2}{|c|}{$\begin{array}{l}\text { Pattern class (\% of for- } \\
\text { est area) }\end{array}$}} \\
\hline & & & & & & & & & & & & \\
\hline & $25 \mathrm{~m}$ & $50 \mathrm{~m}$ & $25 \mathrm{~m}$ & $50 \mathrm{~m}$ & $25 \mathrm{~m}$ & $50 \mathrm{~m}$ & $25 \mathrm{~m}$ & $50 \mathrm{~m}$ & $25 \mathrm{~m}$ & $50 \mathrm{~m}$ & $25 \mathrm{~m}$ & $50 \mathrm{~m}$ \\
\hline Core & $\begin{array}{l}21960 \\
(12.6)\end{array}$ & $\begin{array}{l}13763 \\
(7.9)\end{array}$ & $\begin{array}{l}12733 \\
(7.3)\end{array}$ & $\begin{array}{l}8367 \\
(4.8)\end{array}$ & $\begin{array}{l}10353 \\
(6.0)\end{array}$ & $6147(3.5)$ & $\begin{array}{l}34143 \\
(19.7)\end{array}$ & 22235 (12.9) & $\begin{array}{l}42494 \\
(24.4)\end{array}$ & 31570 (18.1) & 70.0 & 47.2 \\
\hline Islet & $\begin{array}{l}0 \\
(0)\end{array}$ & $\begin{array}{l}655 \\
(0.4)\end{array}$ & $\begin{array}{l}0 \\
(0)\end{array}$ & $\begin{array}{l}364 \\
(0.2)\end{array}$ & $\begin{array}{l}0 \\
(0)\end{array}$ & $\begin{array}{l}485 \\
(0.3)\end{array}$ & $\begin{array}{l}0 \\
(0)\end{array}$ & $\begin{array}{l}988 \\
(0.6)\end{array}$ & $\begin{array}{l}0 \\
(0)\end{array}$ & $\begin{array}{l}1148 \\
(0.7)\end{array}$ & 0.0 & 2.2 \\
\hline Perforation & $\begin{array}{l}131 \\
(\sim 0.1)\end{array}$ & $\begin{array}{l}0 \\
(0)\end{array}$ & $\begin{array}{l}0 \\
(0)\end{array}$ & $\begin{array}{l}18 \\
(0)\end{array}$ & $\begin{array}{l}0 \\
(0)\end{array}$ & $\begin{array}{l}0 \\
(0)\end{array}$ & $\begin{array}{l}198 \\
(0.1)\end{array}$ & $\begin{array}{l}49 \\
(0)\end{array}$ & $\begin{array}{l}574 \\
(0.3)\end{array}$ & $\begin{array}{l}547 \\
(0.3)\end{array}$ & 0.5 & 0.3 \\
\hline Edge & $\begin{array}{l}9505 \\
(5.4) \\
\end{array}$ & $\begin{array}{l}11979 \\
(6.9)\end{array}$ & $\begin{array}{l}4911 \\
(2.8) \\
\end{array}$ & $\begin{array}{l}6758 \\
(3.9) \\
\end{array}$ & $\begin{array}{l}5176 \\
(3.0) \\
\end{array}$ & $6540(3.8)$ & $\begin{array}{l}13441 \\
(7.7) \\
\end{array}$ & $17788(10.2)$ & $12633(7.3)$ & 17200 (9.9) & 26.2 & 34.7 \\
\hline Loop & $\begin{array}{l}0 \\
(0) \\
\end{array}$ & $\begin{array}{l}98 \\
(0.1)\end{array}$ & $\begin{array}{l}0 \\
(0) \\
\end{array}$ & $\begin{array}{l}37 \\
(0)\end{array}$ & $\begin{array}{l}0 \\
(0)\end{array}$ & $\begin{array}{l}32 \\
(0)\end{array}$ & $\begin{array}{l}0 \\
(0)\end{array}$ & $\begin{array}{l}148 \\
(0.1) \\
\end{array}$ & $\begin{array}{l}0 \\
(0) \\
\end{array}$ & $\begin{array}{l}115 \\
(0.1)\end{array}$ & 0.0 & 0.3 \\
\hline Bridge & $\begin{array}{l}200 \\
(0.1)\end{array}$ & $\begin{array}{l}1685 \\
(1.0)\end{array}$ & $\begin{array}{l}182 \\
(\sim 0.1)\end{array}$ & $\begin{array}{l}546 \\
(0.3)\end{array}$ & $\begin{array}{l}162 \\
(\sim 0.1)\end{array}$ & $\begin{array}{l}646 \\
(0.4)\end{array}$ & $\begin{array}{l}395 \\
(0.2)\end{array}$ & $\begin{array}{l}1976 \\
(1.0)\end{array}$ & $\begin{array}{l}574 \\
(0.3)\end{array}$ & $\begin{array}{l}1720 \\
(1.0)\end{array}$ & 0.8 & 3.7 \\
\hline Branch & $\begin{array}{l}980 \\
(0.6)\end{array}$ & $\begin{array}{l}4590 \\
(2.6)\end{array}$ & $\begin{array}{l}364 \\
(0.2)\end{array}$ & $\begin{array}{l}2100 \\
(1.2)\end{array}$ & $\begin{array}{l}485 \\
(0.3)\end{array}$ & $2326(1.3)$ & $\begin{array}{l}1235 \\
(0.7)\end{array}$ & $\begin{array}{l}6228 \\
(3.6)\end{array}$ & $\begin{array}{l}1149 \\
(0.7)\end{array}$ & $\begin{array}{l}5100 \\
(2.9)\end{array}$ & 2.5 & 10.6 \\
\hline $\begin{array}{l}\text { Total area of forest } \\
\text { type (ha and in \%) }\end{array}$ & $\begin{array}{l}32776 \\
(18.8)\end{array}$ & & $\begin{array}{l}18190 \\
(10.5)\end{array}$ & & $\begin{array}{l}16176 \\
(9.3)\end{array}$ & & $\begin{array}{l}49412 \\
(28.4)\end{array}$ & & $\begin{array}{l}57424 \\
(33.0)\end{array}$ & & & \\
\hline
\end{tabular}

